\title{
INTEGRAÇÃO AGRICULTURA-INDÚSTRIA: A RENTABILIDADE NA PRODUÇĀO DE TOMATE PARA INDÚSTRIA
}

PAULO MACHADO MARTINCOWSKI

Orientador: RODOLFO HOFFMANN

Dissertação apresentada à Escola
Superior de Agricultura "Luiz de
Queiroz", da Universidade de São
Paulo, para obtenção do título de
Mestre em Agronomia. Área de
Concentração: Economia Agrária.

PIRACICABA

Estado de São Paulo - Brasil

Maio - 1986 


\title{
DEDICATÓRIA
}

A meus pais

\author{
A Terezinha, pela compreensao e carinho \\ A Diana, que nasceu nesse período \\ A Tati, uma gata amiga
}

A postura de convite ao conhecimento cientifico (mas não à de guardião) 
AGRADECIMENTOS

A Oriowaldo Queda, Maria de Lourdes T. B. Wiend1, Angela A. Kageyama, Abdias Vilar de Carvalho, Noely Martins, Martin Dabezies Antia, João Aurélio Soares Viana, Joaquim Bento Ferreira, pelas discussões, sem dưvida, proveitosas que permitiram a delimitação do problema a ser investí gado, bem como seu posterior desenvolvimento. Com a certeza de que cada un contribuiu na sua medida, mas com 0 mesmo interesse.

Aos pesquisadores do IEA: Maria de Lourdes Barros Camargo, cuja intermediação inicial facilitou muito meus contatos posteriores; Daniel Ribeiro Junior, Silvia de Toledo Arruda e Paul Frans Bemelmans pela atenção dispensada às minhas dưvidas e a José Roberto Viana de Camargo (em memória) pela permissão de acesso aos dados do IEA.

Ao quadro de professores do Departamento de Economia e Socio logia Rural da ESALQ, o qual propiciou, embora nem sempre da melhor forma, a oportunidade de uma melhor delimitação de minhas afinidades cientificas e ideolögicas.

A Angela A. Kageyama e Zilda P.B. Mattos, participantes da mini-banca e a Oriowaldo Queda e Flävio Abranches Pinheiro, participantes da banca examinadora, pelas suas contribuições. Devo ressaltar, entretan to, a particular participação da Angela, pelo que conseguiu agregar ao presente trabalho.

A Rodolfo Hoffmann, preocupado com os limites do trabalho 
cientifico, pela criteriosa, detalhada e preçisa orientação que contribuiu para que chegasse a bom temo esta dissertação.

A Zélia Ferreira de Rezende pela colaboração na fase da datilografia.

Ao CNPq pela ajuda financeira, importantissima, prestada atravès da concessão de bolsa de estudo durante 2,5 anos. 
1. INTRODUÇÃO

1.1. 0 Complexo Agroindustrial

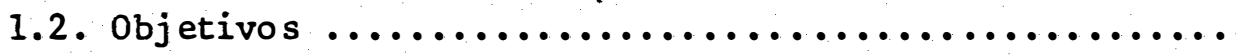

2. O PROCESSO DE INDUSTRIALIZAÇÃO DA AGRICULTURA

2.1. Caracteristicas es senciais $\ldots \ldots \ldots \ldots \ldots \ldots \ldots \ldots \ldots \ldots$

2.2. Particularidades do processo produtivo agrícola ..... 20

3. CUSTOS E RENDIMENTO LIQUIDO

3.1. Produtores integrados com a indústria de processamen-

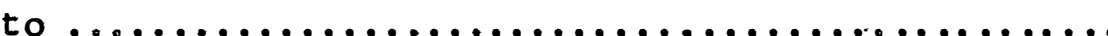

3.2. Custos de produtos agrícolas $\ldots \ldots \ldots \ldots \ldots \ldots \ldots \ldots$

4. OS PRODUTORES DE TOMATE PARA INDOSTRIA

4.1. Medida do rendimento líquido e dados utilizados .....

4.2. Cálculo e anälise do rendimento líquido ...........

5. CARACTERISTICAS DOS PRODUTORES AGRICOLAS INTEGRADOS

5.1. Pequenos produtores $\ldots \ldots \ldots \ldots \ldots \ldots \ldots \ldots \ldots \ldots \ldots \ldots \ldots$

5.2. Produtores de tomate $\ldots \ldots \ldots \ldots \ldots \ldots \ldots \ldots \ldots \ldots \ldots$

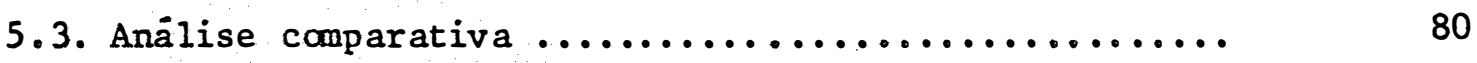

6. CONCLUSסES $\ldots \ldots \ldots \ldots \ldots \ldots \ldots \ldots \ldots \ldots \ldots \ldots \ldots \ldots \ldots \ldots \ldots \ldots \ldots$ 


\title{
INTEGRA G̃O AGRICULTURA-INDÚSTRIA： A RENTABILIDADE NA PRODUÇ̃̃O DE TOMATE PARA INDOSTRIA
}

\author{
Autor: PAULO MACHADO MARTIMCOWSKI \\ Orientador: RODOLTO HOFTIANN
}

\section{RESUMO}

0 primeiro objetivo deste trabalho foi verificar se os produtores de tomate para indústria obtêm rendimento lỉnuido nessa cultura. Para isto, foram utilizados dados de uma pesquisa efetuada pelo Instituto de Economia Agríco 1 a - IEA, en 1979, junto a produtores de tomate para indústria da região de Araçatuba - SP.

Setenta e cinco porcento dos produtores de tomate irrigado entrevistados obtiveram rendimentos positivos de $23 \%$, em média, no ano de 1979 , e dos seis produtores que não obtiveran resultado positivo, cinco não atingiram: níveis de produtividade razoáveis.

O segundo objetivo foi discutir a importância, para o agricultor, decultivos complementares. A literatura analisadamostra que o agricultor explora cultivos complementares para melhorar a utilização dos recursos disponíveis, ten do em vista diminuir os custos de produção. Particularmente, no cultivo do torate, o agricultor cultiva subseqtentemente, na mesma ärea do tomate, outros pro dutos como milho, feijão, ou mesmo cana, acrescentando nouco ou nenhum adubo à terra, aproveitando os residuos existentes no solo, provenientes da cultura do tomate. 
Contrastando, porém, com essa prática dos agricultores, a apuração de custos, de modo geral, não atenta para a utilização conjunta dos recursos de produção. Por consequência, várias pesquisas concluem, incorretamente, que a indústria de processamento se apropria de todo o excedente gerado na produção agrỉcola.

A confrontação dos pequenos produtores de outras natérias - pri mas para a indústria com os produtores de tomate mostrou características distintivas entre estes grupos, resultando em diferenças substanciais na retenção de excedentes entre os produtores de tomate e os outros grupos analisados. A apropriação de excedentes pelos produtores agrícolas integrados com a ąroindústria dependeria do poder de barganha de cada setor agrícola frente ao setor agroindustrial.

Por fim, traçaram-se as principais características do processo geral de industrialização da agricultura, evidenciando a intensificação dos vín culosda produção agrícola ao setor industrial. 
THE AGRICULTURE-INDUSTRY INTERRELATION: PROFITABILITY

OF PRODUCTION OF TOMATO FOR INDUSTRY

Author: PAULO MACHADO MARTINCOWSKI Adviser: RODOLFO HOFFMANN

\section{SUMMARY}

The first purpose of this dissertation was to verify whether the fanmers of tomato for industry reach positive net income. In order to do this, data were utilized from a research conducted by Instituto de Econo mia Agrícola - IEA, in 1979, with famers of tomato for industry from the region of Araçatuba in São Paulo.

Seventy five percent of i rrigated tomato farmers interviewed then reached on the average a $23 \%$ positive net income. Among the six famers who did not reach positive results five did not get reasonable productivity levels.

The second purpose was to discuss how important complementary crops are to the fanmer. The analysed literature shows that famers use complementary crops in order to minimize his production costs. Particularly in the tomato crop the farmer cultivates subsequent 1 y in the same area other crops as corn, bean or even sugarcane, adding little or no fertilizer to the soil, since he knows there are residuals of fertilizer from the 
previous crop.

However in contrast to famer's practice, the computation of costs generally doesn't consider carefully joint production. Consequently, several researches conclude incorrectly that farmers who supply industry have their surplus appropriated by processing industry.

The analysis of small farmers that produce other industrial raw materials and farmers of tomato for industry showed that they have different characteristics. This results in substantial diferences in surplus appropriated. The surplus appropriation would depend on bargaining power of each agricultural sector in relation to the processing industry.

Finally, the main characteristics of agriculture industrialization process were outlined, emphasizing the strenghtening of the linkages between agriculture production and the industrial sector. 
1. INTRODUÇ,̃̈O

\subsection{O Complexo Agroindustrial}

O setor agrícola brasileiro vem sofrendo profundas alterações nas ültimas décadas, destacando-se a crescente vinculação entre a agricultura e a indústria.

A agricultura utiliza cada vez mais insumos industriais para produzir, ao mesmo tempo que uma proporção crescente da sua produção è vendida para as agroindústrias.

MULLER (1982, p.83) afirma que "em face da massa de necessidades e interesses de corte industrial que perpassa todos os setores do complexo agroindustrial, pode-se asseverar que a industrialização dos mesmos é a tendência predominante e, tudo leva a crer, irreversíve1... Esta tendência evidencia que as características dessa industria lização regularão a expansão ou o bloqueio dos setores industriais e agrícolas." 
SZMRECSÁNYI (1983, p.7) sugere um esquema de anälise do setor agropecuārio que permite melhor captar suas transformações estruiu rais e qualitativas. Nas palavras desse autor, "o setor deixa de constituir um compartimento semiautönomo e fechado, para tornar-se um sistema aberto e integrado aos setores que lhes são complementares no contex-to da economia como um todo".

Desse modo, o complexo agroindustrial è formado pelos seguintes setorés:

- produção : engloba os vārios tipos de cultivos e/ou criações. agropecuāria

- instituições : envolve os värios serviços prestados ao setor agropecuärio (crédito, assistência técnica, extensão, pesquisa, etc.).

- indústria de : abrange os ramos industriais e comerciais que se insumos orientam para o atendimento das necessidades produtivas agropecuárias (corretivos, fertilizantes, defensivos, implementos, equipamentos, etc.).

- comercialização : diz respeito aos serviços de estocagem e comercialização dos produtos agropecuārios (cooperativas, atacadistas, redes de comercialização, etc.).

- indústria de : inclui os ramos industriais com produção predomiprocessamento nantemente baseada em matērias - primas de origem agropecuāria. 
Figura 1. Esquema do Complexo Agroindustrial

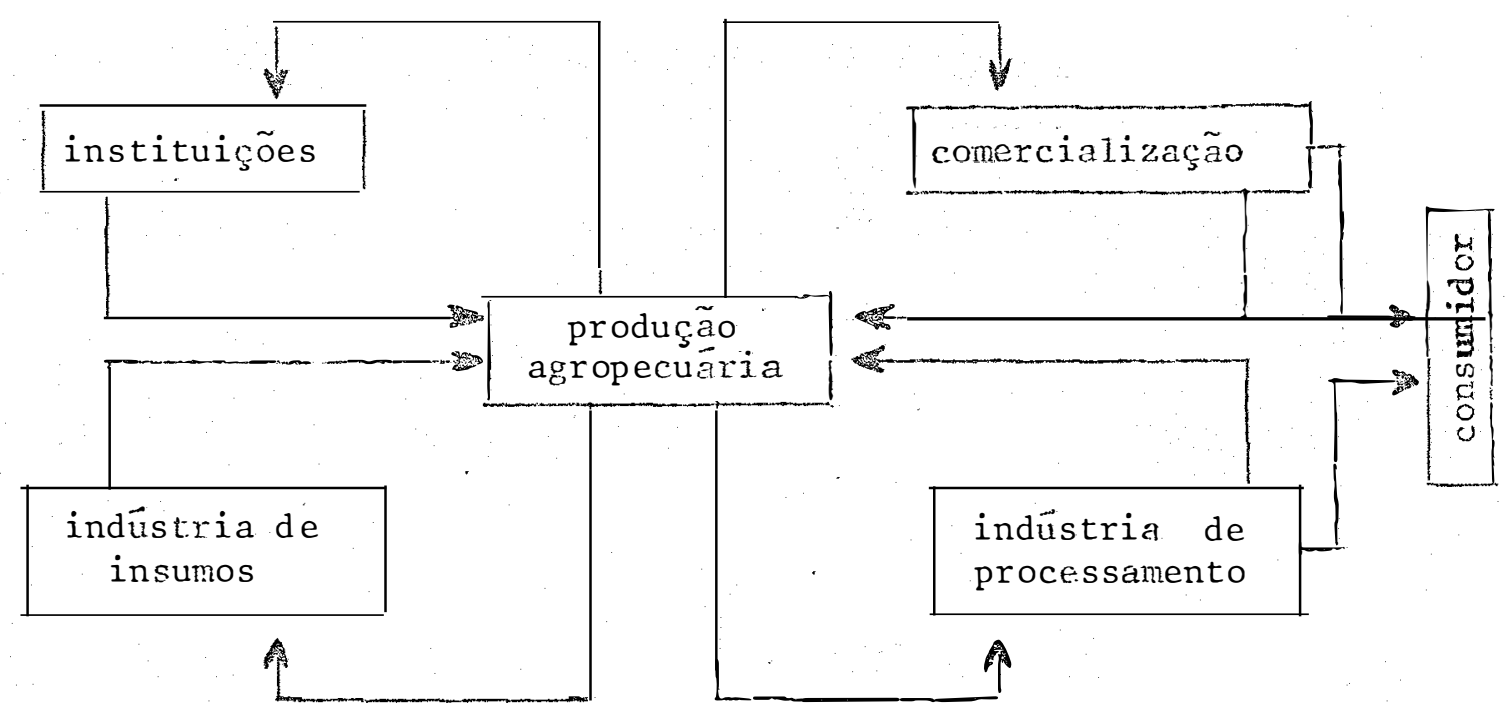

FONTE: SZMRECSÄNYI (1983)

Cabe ressaltar que as articulações mostradas no esquema não se aplicam igualmente para os värios produtos agropecuários. No caso do feijão no Brasil, por exemplo, o produtó não sofre nenhum processamento industrial, sendo encaminhado diretamente para os canais de comercialização. Por outro lado, é bom lembrar que a inserção de um particular produto dentro do complexo agroindustrial pode se alterar com o decorrer do tempo. Utilizando-se o mesmo produto como exemplo e ainda para o caso brasileiro, se o consumidor se habituar (ou for habituado) em algum momento a fazer uso de feijão enlatado, a inserção desse produto no complexo agroindustrial será outra. Ainda mais, um produto como tomate, que atualmente apresenta dois caminhos dentro do esquema, conforme seja processado ou não, talvez, no futuro, seja consumido fundamentalmente como produto transformado, deslocando a produçäo do tomate de mesa. 
Para este trabalho, interessará a ligaçäo entre o produtor agropecuärio e a indütria de processanento que fabrica os seus produtos a partir de matëria-prima de origen agropecuảria. Ao centrar-se a análise na relação entre a agricultura e a indûstria de transformação ou agroindústria, nota-se que as formas de relacionamento podem adquirir difereṇtes conotações, conforme o produto considerado e o tipo de produtor agricola envolvido.

GUTMARÃEs (1979, p. 134) enfatiza que os setores "a jusante da agricultura jmpõem, à sua maneira, as quantidades e tipos de produtos mais conformes às exigências de transfornação industrial".

SORJ (1980, p. 45) caracteriza essa necessidade da agroindüstria de garantir o seu processo produtivo quando afima que "a indüstria de processamento apöia a modernização da agricultura pela necessidade de assegurar uma oferta estável e crescente de produtos com qualidade homogênea". GUIMAR̃̃es e SORJ apontam dois fatores básicos para o funcionamento do processo produtivo na agroindústria: regularidade e qualidade adequada da matéria prima de origem agropecuária. Ambos, contudo, não qualificam as condịções em que se dá ou não a modernização. Não è a partir do simples apoio ou imposição que se pode inferir uma casualidade linear entre a existência de relação com indústria de processamento e a mo dernização tecnológica do produtor agropecuärio.

Provavelmente, o tamanho do setor agroindustrial particular è fator importante na atualização do nível tecnológico efetuada pelo produtor agropecuário. 
Por outro lado, qual a vantagem do agricultor em se desenvolver tecnologicamente? Basicamente, um grau maior de desenvolvimento tecnológico implica aumento de produtividade que levaria a custos mais baixos. A redução da incerteza tambēm seria uma decorrência do desenvolvimento tecnológico na medida em que o agricultor teria efetivanente maior controle sobre o processo produtivo.

Värios autores discutem como os preços do produto agrícola e dos insumos são afetados pela estrutura de mercado a jusante e a montante da agricultura. SINGER (1968, P.298) coloca que "a separação entre agricultura e indūstria, que decorre da desvinculação desta daquela, é superada pelo dominio da primeira pela última, que se realiza geralmente pela constituição de mercados de produtos agrí. colas de regime monopsônico ou oligopsônico".

SORJ (1980, p.46) destaca que "a relação entre produtores agropecuārios e as indústrias de processamento ou firmas comercializadoras apresenta uma tensão básica. Quanto menor for o preço pago ao prọ dutor, maiores serão os lucros e competitividade no mercado". Para GUIMARÃES (1979, p.116) "o mais importante dos efeitos da integração agroindustrial é a supressão da livre concorrência com repercussão direta no mecanismo de preços,que passa a ser ditado pelas indústrias a montante e a jusante da produção agrícola e em bases tendencialmente monopolistas, dado o domínio incontestảvel que essas indústrias exercem sobre o mercado". KAGEYAMA (1984, p.3) destaca que "as indústrias processadoras têm uma forte capacidade de exercer influência sobre a agricultura, dada a alta percentagem de produção agrícola que consomem, mas os dojs polos 
industriais exercem essa influência e a principal modalidade se dá através do mecanismo de preços".

Nota-se em todos estes comentärios uma ênfase no poder de determinação dos preços por parte da agroindüstria e/ou indústria de insumos. Porëm, SORJ e WILKINSON (1983, p.167) destacam a conseqüência desse poder para o produtor agrícola quando afirmam que "o complexo agro industrial se transforma no beneficiário principal do sobretrabalho dos produtores agrícolas".

Assim, uma interpretação comum na literatura è que os prodü tores agropecuārios não auferem rendimentos líquidos positivos na cultura contratada com a agroindústria. Algumas pesquisas, que serão discutidas em outra parte deste trabalho, chegam a esta conclusão sem a necessário profundidade e/ou clareza na estrutura de custos das culturas como un todo e particularmente nas que poderiam possuir relações de complenentarida de com a cultura contratada.

Um outro questionamento que pode ser feito a este tipo de interpretação é o fato do produtor agropecuário permanecer em uma atividade que não lhe traz vantagens. Seria razoável pensar que este produtor acabará mudando de cultivo ou pelo menos de indústria se, após chegar ao ponto ótimo de seu processo produtivo, aindanão estiver auferindo rendimentos líquidos positivos.

Ademais, sabe-se que a tecnologia em geral permite uma margem de manobra bastante razoável no tocante a modificações nas culturas escolhidas e sendo assim, não se pode generalizar a situação dos avi cultores analisada por SORJ, POMPERMAYER e CORADINI (1982) que uma vez 
articulados com a agroindústria avỉcola teriam grandes dificuldades para mudar de produto.

Mesmo quando aufere rendimento liquido positivo na cultura contratada com a agroindústria, esperamse que o produtor agrícola se valha de cultivos complementares quanto à utilização de meios de produção e, ainda mais, que mude de cultivo no caso de maior possibilidade de apropriação de ganhos.

Outrossim, não se trata de negar que haja apropriação de excedente por outros setores, mas sim de mostrar que carece de fundainento a afimativa feita por diversos autores, de que na ligação agroindús tria / produtor este não aufere rendimentos líquidos positivos na cultura ou criação cuja produção se destina à agroindüstria.

\subsection{Objetivos,}

O objetivo geral deste trabalho seria contribuir para lançar alguna luz sobre a natureza das relações presentes entre o produtor agropecuário e a agroindústria, analisando em que medida a agroindústria se apropria do sobretrabalho gerado pelo produtor agropecuário.

Para isso, será estudado o caso de produtores de tomate que fornecem matéria prima para a indūstria processadora, perseguindo os seguintes objetivos especificos: 
1) verificar se os produtores de tomate ligados à agroindústria auferem rendimentos 1íquidos positivos nessa cultura.

2) discutir a importância, para o agricultor, da produção conjunta e, em caso positivo, analisar como é feita, atualmente, a apuráção de custos. 
2. O PROCESSO DE INDUSTRIALIZACÃO DA AGRICULTURA

Nesta parte do trabalho procura--se evidenciar as principais caracteristicas do processo, mais geral, de industrialização da agricultu ra. Ele parece alcançar seu ponto mais elaborado, através dá representação denominada complexo agroindustrial (CAI).

Cabe lembrar que não se pretende alcançar uma reconstitui ção histörica do processo mais geral, mas apenas delinear suas caracterís ticas essenciais, até atingir o estágio atual, o CAI. Serả discutido, também, como o processo de industrialização da sgricultura mođifica a apropriação do excedente de um setor pelo outro.

Na seção seguinte, procura-se ressaltar particularidades do processo produtivo agrícola quando contraposto ao processo produtivo industrial.

\subsection{Caracteristicas essenciais}

o processo de industrialização da agricultura envolve o re- 
lacionanento entre a agricultura e indústrias que processam ou benefician a matéria-prima agrícola, além de indústxias que fornecen insunos à agricultura. Na fase inicial desse processo, para o caso brasileiro, é insig nificante, ou mesmo nula, a participação dos setores a montante da agricultura. GJTMARÃES (1976, p.8.) destaca que "os setores industriais forne cedores de insumos agrícolas só começam a implantar-se a montante da agrị. cultura numa fase ulterior do desenvolvimento da economia, depois de um núcleo de certa magnitude se haver instalado a jusante da agricujtura e de este impor, à sua maneira, as quantidades e os tipos de produtos mais conformes às exigências de transformação industrial".

A ligação entre a agricultura e a indústria de processamento è a mais relevante nessa etapa inicial. Nesse sentido, o mesmo autor ressalta a presença de inovações nas propriedades canavieira e cafeeira "por força das exigencias de competição estrangeira que nos impunha levar ao mercado produtos de qualidade melhor". Estas inovações, porém, estavam restritas às tēcnicas de processamento, refletindo uma "industrializa ção da agricultura", iniciada em nosso país, a partir da periferia dos processos produtivos" (GUIMARÃES, 1979, p. 62,65).

Na realidade, as propriedades canavieira e cafeeira passam por processos distintos. No caso da cana, a década de 1870 registra uma tentativa de separação entre o processo agrícola e o industrial, representada pelos engenhos centrais. Este fato acelera a incorporação de novos maquinismos para a transformação de cana, que permitem a obtenção de um produto de melhor qualidade comercial, o açūcar centrifugado. GUI= MARÃES, entretanto, destaca a reversão dessa tendência, através da expan 
são "de un curso evolutivo que une, no açücar, em grandes unidades produtivas, os novos industriais usineiros aos mais poderosos latifündios cana vieiros", GUTMARÃES (1979, p.66)\%. Já no café, a propriedade agrícola ca minharia no sentido de incorporar melhoxias técnicas no beneficiamento do café. Segundo VIOTTI DA COSTA (1966, p. 182), "em muitas fazendas, o café era transportado para a casa de máquinas, pilado, descorticado, escolhi. do, brunido, ensacado e pesado, tudo mecanicamente... Já ná cultura pro priamente dita, prevaleciam os métodos manuais, ditados pela rotina. Na maior parte das fazendas, continuava-se a cultivar a terra apenas com o auxílio da enxada". Verifica-se, por essa descrição, que as técnicas modernas são aplicadas inicialmente às atividades não propriamente agríco las, ainda que no ámbito agrícola. A ligação entre agricultura e indús tria de processamento se dá sob comando único e em um mesmo ambiente, o rural. Assim, não é a atividade industrial que condiciona a atividade agrícola, mas antes, o conträrio, é a atividade agrícola que condiciona a atividade industrial.

Na relação entre a agricultura e indüstria de processamento, enquanto agentes económicos distintos, não necessariamente a indústria im põe, à sua maneira, suas necessidades, ou seja, hä situações em que os vínculos se limitam a operações de troca em um mercado atomizado. Nesse caso, as compras de matēria-prima não estariam concentradas em poucas empresas, sugerindo alternativas aos produtores agrícolas. Logo, torna se indicado caracterizar, no início da formação industrial brasileira, a estrutura de un ramo industrial e, a partir daí, evidenciar ou não esse

* QUEDA (1972, p. ) destaca que essa união não se verifica en São Paulo. 
poder de imposição.

Nesse sentido, CANO, em sua pesquisa. sobre o processo de concentração industrial, destaca o ramo têxtil como sendo a principal atividade de transformação industrial do país, no início desse século. En quadra esse ramo nas atividades que chama de 'complexas', isto $\bar{e}$, "eram aquelas mais sujeitas a economias de escala, a uma mecanização mais inten sa e a um uso maior de energia elétrica ... essas indústrias praticamente eram fechadas à entrada de pequenas empresas e raras eram as de médio porte" (1977, p. 207). No censo de 1907, dos 31 estabelecimentos texteis, representando mais de $42 \%$ do capital total da indústria pauIista, 19 eram fiações e tecelagens de algodão. Dados evidenciam que essas 19 empresas tinham, em média, cerca de 340 funcionários por empre s a $($ p. 292).

o autor ainda observa que a taxa média de lucro devia ser alta, pelo menos para às grandes e médias empresas modernas, face à inexistência de concorrência $(1977$, p.213). Essa inexistência de competição se devia a fatores como atuação da empresa em diferentes mercados regionais ou locais, diferenciação do produto (em 19 empresas de algodão, algumas produziam 'brins', outras 'lonas', outras 'morins') e a convivência entre empresas com tecnologia moderna e tecnologi.a antiga, jä que o pre co demercadofixado anteriormente pela'antiga'permitia uma taxa de Iucro maior à'moderna'. Mais adiante, esclarece que os grandes grupos nacionais "não concentraram maciçamente seus capitais em reduzido núnero de negócios, preferindo, ao conträrio, diversificar suas'carteiras de inversões' com o que, obviamente, diminuỉam o risco do capital" (CANO, $1977, \mathrm{p} .225)$.

REISS desenvolve mais o aspecto do risco condicionando as atividades industriais à atividade dominante, a exportação do 
café, a qual envolvia altas e baixas, motivo potencial de

possiveis perdas. Afirma que "Nas fases iniciais do crescimento industrial no Bra sil, os investimentos em atividades industriais deveriam gerar lucros mais elevalos que outros tipos de investimento, mas, na verdade, os produziriam menos freqüentemente, e muitas vezes tais investimentos resultariam em grandes perdas e falências" (1983, p. 80), concluindo mais adiante que "Não é que as atividades industriais fossem pouco atrativas às grandes unidades de capital. Mais propriamente, em razão de seu tamanho, o grande capital podia ser mais prudente através da diversificação do risco*e, mais do que isso, reduzi-1o ao integrar as funções industrial, comercial, agrícola e financeira em seus processos de crescimento" (1983, p. 89). Em suma, pode-se caracterizar o ramo industrial textil como sendo formado por empresas grandes (para a época) que obtëm uma taxa de lucro alta, ainda que instável.

ALBUQUERQUE, porém, analisando especificamente o algodão, revela os principais determinantes dessa taxa de lucro alta. Assin, "já no início da ültima década do século XIX, a indústria têxtil tem poder de articulação suficiente para pressionar o Governo no sentido de uma intervenção tarifária protecionista em níveis mais elevados do que o existente" (1982, p.88) e, de fato, estas tarifas se mantêm até 1930, embora em graus variáveis. O argumento da proteção à indústria in fante parece ser o ponto básico que viabiliza as vendas, e seu nível crescente. Um fato corrobora essa estratégia: uma entrevista com o proprietārio de uma das maiores empresas téxteis, retratando certa tranquilidade e segurança do empresärio. "Os custos de

* 0 autor quer referir-se, na verdade, à diversificação de atividades, visando redução do risco. 
produção não entram no meu preço de vendia, Eu sempre me mantenho a par do mercado estrangeiro e defino o preço de minhas mercadorias 5 ou 10 por cento abaixo daquele pelo qual possa ser importado" (1982, p, 90). o que ele não esclarece, embora saiba, é que a tarifa sai em função da prōpria pressão dos empresärios e, portanto, tende a ser favorável, de forma a evitar prejuizos.

o outro ponto sobre o qual incidem pressões é quanto aos custos, embora não haja mençạo a nenhuma associação dos empresários com esse objetivo, pelo menos no início. A pressão sobre os custos e, particularmente, sobre os produtores de algodão poderia ser direta ou indireta. Direta quando as fäbricas tẹxteis "tinham descaroçadores e compravam o algodão em caroço, quase sempre por meio de agen tes, que eram negociantes de sècos e molhados estabelecidos nas zonas algodoeiras, ... fornecendo gêneros ou dinheiro aos lavradores e, na safra, recebiam algodão em pagamento" (ALBUQUERQUE, 1982, p. 206). A pressão podia ser indireta, se se interpunha entre a enpresa e o produtor, o maquinista que descaroçava o algodão,

Em termos de regularidade de entrega, conquanto houvesse problemas eventuais de oferta a nível estadual, estes eram facilmente resolvidos pela 'importação' de algodão nordestino, ao passo que em termos de qualidade, "De um modo geral, o algodão paulista era considerado bom... características ligeiramente superiores às médias; cor branca; resistência boa; elasticidade regular" (1982, p.142). Então, se por um 
lado, não havia indústrias de insumos, por outro, a qualidade do algodão atendia às exigências de um mercado incipiente.

Porém, esse processo deu somente seu primeiro passo. Os laços tendem a estreitar-se cada vez mais. Nesse sentido, ALBUQUERQUE registra que na fundação da Bolsa de Mercadorias de São Paulo (BMSP), em 1918, os industriais comentavan sobre a importância desse organismo, no sentido de "assegurar um fornecimento de matérias primas, parcelado e oportuno", conquanto funcionasse também como padronizador e controlador de produção. ALBUQUERQ̨UE. (1982, p. 123).

Posteriormente, em 1924, uma reforma no Instituto Agronômico de Campinas (IAC) reorienta a pesquisa para "melhoria da qualidade das fibras cotadas pela BMSP, propiciando melhores preços ao algodão, dotando a indūstria têxtil com maior produção de matêria-prima e fibras mais longas" (ALBU゚UPROUE, 1982, p. 119).

Por essa êpoca, jā se pode falar em um complexo algodoeiro paulista composto pelo IAC, BMSP, produtores de algodão e a indüstria têxtil, embora aincia sem envolver indústrias a montante da agricultura. A BMSP tem um papel decisivo na articulação entre a indústria textil e a produção alģodoeira, quer seja disseminando informações aos produtores, quer seja, principalmente, definindo critêrios para clas sificação, os quais permitem controlar o preço da matēria-prima em níveis satisfatōrios para as empresas. O autor ainda fornece uma rápida imagem do processo produtivo na época. Esse processo "era simples, com um mínimo de maquinaria, sem adubos químicos, sem alterações profundas 
no ritmo de trabalho... (permitindo)* avaliar o nexo das transformações - ou não - a nível das reỉações sociais da produção" (1982, p.114).

o passo final para a estruturação do complexo algodoeiro seria por volta de 1948, com a Anderson Clayton (ACCO) e a SANBRA, que nessa época já são responsáveis por cerca de 50\% de todo o beneficiamento do algodão paulista e, particularmente "A ACCO, sem conseguir penetrar no monopólio das sementes, já integrava en sua operação desde a compra de algodão em bruto até o financiamento dos produtores, comercializando máquinas, adubos e inseticidas, com corpo de engenheiros à disposição do agricultor", sendo necessārio, entretanto, ressalvar que a comercialização de insumos necessärios ao proces so produtivo agricola implicava as possibilidades de produção interna ou import ação. (ALBUQUERQUE, 1982, p. 128).

Adiante, este aspecto é esclarecido: "Quanto ao fornecimento de insumos a mesma empresa, já em 1941, construía a primeira fábrica de adubos, em Araraquara (em 1947, a segunda, em Bauru)... Quanto à mecanização da lavoura vem importando e financiando tratores ... Espera-se que em 1951 esteja em produção a Fábrica de Inseticidas Capuava" (1982, p.186). Portanto, na década de 40, verifica-se a imimplantação de indústrias a montante da agricultura, dando feições avançadas ao complexo algodoeiro. Estas feições do complexo algodoeiro são representadas pela capacidade, em grau variàvel, de impor preços, pela adequação do produto agrícola às necessidades industriais e pela capacidade de coordenação de entrega da matéria-prima, conforme suas necessidades produtivas.

* Observação entre parêntesis minha (PrM). 
E importante comentar como a produção agrícola se adapta às exigências da agroindústria. Com esse objetivo, vale detalhar os requerimentos do processo produtivo industrial.

A indústria de processamento necessita regularizar seu processo produtivo, visando a minimização de custo e o fornecimento re-gular do produto final para os consumidores. Essa regularização é conse guida, da melhor forma para a industria, se a matéria-prima chegar à in dústria no momento em que vai ser processada. Nesse caso, não hä necessidade de manter äreas para estocagem de maťéria-prima, nem muito menos dispender capital com essa matéria-prima estocada, além do transporte in terno que envolve custos não desprezíveis.

Caso a indústria não consiga receber os produtos somenț no momento de seu processamento, duas alternativas existem: ou se opta pela estocagem de matéria-prima, como descrito antes, ou se dimensiona:a capacidade produtiva de forma a absorver este atraso no recebimento de matéria-prima. Nas duas situações, a minimização dos custos não serä atingida. Por certo a indústria opera com um estoque de matéria-prima,o qual decorre da própria duração do processo de trabalho (matéria-prima em processamento) e da probabilidade de ocorrência de anormalidades quais quer no processo produtivo (estoque de segurança). Essas anormalidades podem até incluir pequenos atrasos no recebimento da matéria-prima, mas certamente o estoque deverá ser mínimo. Então, em condições normais de operação da unidade industrial, o estoque de segurança, a depender do ramo produtivo, serā de 1 a 2 semanas de produção, se chegar a tanto, 
e o motivo é a necessidade de minimizar o capital empatado em estocagem de matéria-prima.

Por consequência, a indüstria objetivará regularizar o suprimento de sua matēria-prima. Ocorre, porém, que a principal matēria -prima utilizada é o produto agrícola que apresenta uma instabilidade in trínseca, decorrente de sua dependência, em alto grausdas condições naturais.

Um tipo de instabilidade no processo agrícola com consequêencias para a indústria de processamento são as adversidades climáticas como geada, vento ou ainda a ocorrência de pragas que podem 1 evar, muitas vezes, a uma perda total da colheita. Desse modo, o risco da pro dução agrícola émaior que o risco da produção industrial, pois a agricultura estä exposta aos fatores naturais, enquanto que a indüstria controla muito ben esses fatores. Então, a agroindústria efetua contrato com un numero maior de produtores agrícolas pois sabe que alguns deles perderão a colheita por adversidades climáticas ou ocorréncia de pragas. Através da contratação de una quantidade maior a agroindústria garante o recebimento da quantidade que realmente necessita.* Assim, a agroin dústria deve utilizar un indice de perdas da colheita, embora possua certo estoque interno, sob pena de comprometer o fluxo de seu processo produ tivo. E claro que a quantidade contratada não deverà ser excessivamente alta, pois isso também poderá trazer prejuízos para a indústria de process amento.

* Levantamento proveniente de contratos efetuados com produtores agrícolas por una agroind ústria de tomate, em 1982, revela una perda de $30 \%$ da quantidade contratada. 
No entanto, existem outros tipos de instabilidade no processo agrícola que podem ser superadas coma utilização da tecnologia. Lo go, a indústria atuará junto ao produtor agrícolds no sentido de que este utilize tecnologias que minimizem ou mesmo evitem a influência dos fa tores naturais, e, se necessärio, fiscalizará certas fases do processo pro dutivo agrícola para garantir os requisitos técnicos do produto agrïcola necessäriós às condições do processo produtivo industrial ou necessários ao seu produto final.

Embora sem assumir a responsabilidade pelo processo produ tivo agrỉcola, a agroindüstria pressiona e, às vezes, até impõe a organi zação desse processo, seu grau tecnológico e o tipo de mão-de-obra, entre outros aspectos.

Interessa ressaltar que, anteriormente à integração com a agroindústria, o produtor agrícola comercializava seu produto con o in termediärio, que efetuava pequenas transformações no produto, se necessá rias, e o encaminhava para a rede varejista. Nessa situação, "geralmente interessa a este (o capital mercantil)* a manutenção de ba ses técnicas tradicionais na produção agrícola, des de que a mudança dessas bases implica geralmente maiores custos monetários e portanto eleva o preço de compra pelo comerciante". (HofFMANN et alii, 1985, Vo1.I,n.66).

De modo geral, a agroindústria possui um poder de barganha maior, relativamente ao intermediário, de impor preços baixos ao produtor agrícola. A unidade industrial consegue concentrar un nümero

* Observação entre parēntesis minha (PMM). 
de produtores agricolas, que the fornecem matëria-prima, muito maior que um intermediário. Alëm disso, a comprá direta pela agroindústria elimina fases da comercialização efetuadas pelo intermediärio.

Em suma, a integração do produtor agrícola com a agroindústria, deslocando a atuação do intermediärio, propicia à indústria condições de extrair uma parcela maior do excedente gerado na produção agríco1a. As inovações tecnológicas, posteriormente, é que definirião un contro le maior sobre o proceșso produtivo agrícola, bem como a possibilidade de aumento da extraçäo de excedentes pelo setor industrial.

\subsection{Particularidades do processo produtivo agricola}

Com o intuito de ressaltar algumas dessas particularidades, procurar-se-à, em seguida, comparar o processo produtivo industrial ao processo produtivo agrícola.

Os processos industriais apresentam a característica de que a peça trabalhada é matéria sem vida e imóvel. Pelo fato de a peça não ter vida, o processo de produção na ind ústria é definido pelo homem.* As forças da Natureza, nesse caso, estão controladas, una vez que

* Na verdade, definido pelo capital, posto que no capitalismo o homem per sonifica as decisões do capital. 
A mobilidade da peça implica a possibilidade de seu transporte durante o processo, Então, a peça pode passar por postos, onde são executadas as operações. Dito en outras palavras, as funções de transporte e operação são separáveis. Pode-se processar uma peça ou um conjunto de peças e depois transportā-las para outro posto, onde será efetuada a etapa posterior, Ora, mas se é possível suprir-se cada posto de serviço com peça ou peças na correspondente fase de trabalho, as operações podem ser simultâneas e, com isso, o tempo de produção pode ser enormemente reduzido. Como MARX observa, "De uma sucessão no tempo, os diversos processos graduais transformam-se em uma justaposição no espaço. Daí o fornecimento de mais mercadorias prontas no mesmo período de tempo" (1985, p.273). Contudo, a simultaneidade de operações carrega consigo a interdependência das máquinas, no sentido de que qualquer máquina que pare, automaticamente alterará o tempo de produção total, a não ser que haja um estoque de segurança. Mesmo assim, aquele estoque é finito e, uma vez esgotado, aumentará o tempo de produção.

o balanceamento dessas operações simultâneas permitirá que se regularize as necessidades de mão-de-obra que, por outro lado, são contínuas, supondo-se um nível de produção e uma dada tecnologia, além, é claro, de uma demanda pelo produto em fabricação.

Assim, observando-se uma indústria constata-se que, cho va ou faça sol, lá. funciona um processo produtivo organizado pelo homem com base em operações simultâneas. Mais, na indústria o tempo de produção, em regra, está muito próximo do tempo de trabalho. 
o processo produtivo agrî́cola, em geral, envolve as operações de preparo do solo, plantio, tratos culturais e colheita, sendo que, analogamente à indústria, estão representados por essas operações conjuntos de tarefas, A planta, mais especificamente a semente, apre senta uma característica marcante, distinta da indústria, qual seja, è uma matéria orgânica e viva. Por ser viva, está sujeita a um ciclo biológico, prescrito pela Natureza. Assim, as fases 1istadas não acontecem en função do homem querer mas, antes, é o homem que se adapta a essas fases.

Em cada região para cada tipo de solo, pocie-se plantar certos produtos, mas em determinada época do ano. Mais ainda, algumas fases do ciclo produtivo não requerem trabalho humano, sendo, nessas ocasiões, somente a Natureza responsável pelas transformações necessārias, através de determinadas condições climáticas. Por outro Iado, em certas fases do ciclo agrícola, por exemplo na colheita, o intervalo de tempo é fundamental pois, caso não seja seguido, o fruto ou cereal colhido já não estará em condições de ser consumido. Então, as diferentes fases do ciclo produtivo agrícola requerem diferentes quantidades de mão-de-obra, podendo até ocorrer a não necessidade de mão-de-obra, caracterizando uma exigência de mão-de-obra variāve1, durante o ciclo produtivo. 
A outra característica do processo produtivo agrícola, como se apresenta na realidade, é que a planta não se move, inversamente ao que acontece na indūstria. Há necessidade de algum meio, terra por exemplo, para que se possa acomodar todas as plantas, inclu sive prevendo um espaço para seu crescimento. Decorre disto que a mäquina deve se deslocar até a planta, ou seja, as funções de transporte e operação não podem ser separadas no ciclo produtivo. Então, efetuase a operação em uma unidade de planta e, em seguida, locomove-se até a outra unidade, e não como na indústria onde o homem permanece parado e o que se movimenta é a peça. De certo, é fato que em algumas ope rações cono a irrigação pode-se, em alguns casos, alcançar a planta sem ir até ela, mas este não representa o caso mais comum. Assim, em geral, a mäquina, na agricultura, deve prover duas funções, ou seja, transporte e operação, defrontando-se, então, com as irregularidades do solo, as quais, em certos casos, impossibilitam até a própria mecanização. Mais ainda, o ritmo de trabalho na agricultura é dado, em maior grau, pelo operador da máquina e não pela máquina, como na indústria, já que o transporte envolve um intervalo de tempo na agricultura muito maior do que na indústria. A prōpria supervisão do processo de trabalho é bem mais difícil na agricultura porque as operações envolvem deslocamento do operador e, portanto, estão dispersas em uma ārea bem maior do que na indūstria, onde, ao contrārio, são concentradas em pequenos es paços, o que facilita a supervisão

Por ültimo, e não menos importante, pelo fato da atividade agrícola requerer condições climáticas Ł terra em extensão, o processo produtivo se desenvolve a céu aberto, daỉ lecorrendo a impor- 
tância do risco relativo às condições climáricas. Assim, analisando-se o processo produtivo agrícola, observa-se o seu condicionamento, em alto grau, à Natureza, sua não simultaneidade acarretando um tempo de produção elevado, necessidades de mão-de-obra variáveis durante o ciclo, além de risco elevado.

Relativamente à indústria, hä muitos degraus a percorrer e enbora esteja se estendendo o modo industrial de produzir à agricultura, esta apresenta particularidades substantivas. Valeria; ainda, avançar un pouco sobre a introdução de máquinas na agricultura. Para isso, torna-se necessärio lembrar algumas conseqlências de sua introdução na indústria. Assim, MARX observa que "A máquina, que possui habilidade e força no lugar o operário, é ela mesma a virtuose, que possui uma alma própria nas leis mecānicas que operarn nela... a atividade do operário, reduzida a una simples abstração de atividade, è determinada e regulada em todas as suas componentes, pelo movimento da máquina, e não vice-versa" (1981, p.89.* A esse propósito GRAZIANO IJA SILVA lembra que "a implantação de maquinariadestrōi esse princípio de divisão do trabalho de adap tar cada uma de suas fases à habilidade manual dos operários, libertando-o por completo do homem que o comandava. Agora, na maquinaria nem a intensidade, nem o ritmo, nem mesme os movimentos do processo de traba1ho dependem da habilidade dos trabalhadores". (1980, p.52). NAPOLEONI, entretanto, destaca o ângulo crucial da questão: "Em todas as tecnologias que precederam o capitalismo.... instrumento de trabalho era o termo de mediação entre o trabalho e a natureza, ou seja, o trabalho agia sobre a natureza por meio do instrumen-

* Observação de MARX, retirada de NAPOLEONI (ver bibliografia). 
to de trabalho... Com as mãquinas, essa relação se apresenta, de certo modo, invertida, jầ que o instrumento não estả mais em posição inter mediária e, portanto, não desempenha mais uma função de mediação. E precisamente essa função de mediação que è despejada sobre o operärio" (1981, p. 88).

$\mathrm{Na}$ agricultura, è exatamente essa inversão que apresenta problemas para sua consecução. Na indústria, o operador aproxima tão somente a peça, colocando-a em uma guia, ou, em outros casos, segura a peça para que a máquina execute o serviço. Já na agricultura, o inverso acontece, ou seja, dado que a planta não se movimenta, o operador coman da a máquina, aproximando-se da planta, acionando-a para que, então, ela efetue as operações, 0 operador atua sobre a máquina efetuando operações que permitirão a esta desenvolver sua função.

Se è verdade que a mäquina pode substituir a atenção, o cui dado do trabalho humano, näo é menos verdade que, na agricultura, a intensidade, o ritmo do processo de trabalho ainda dependem, em alto grau, do homem.

Por outro lado, importa ressaltar que a questão fundamen tal é se essas particularidades do processo produtivo agrícola são intransponíveis. Evidentemente que não, pois, conforme jä salientado, a pesquisa objetiva justamente resolver esses problemas. GRAZIANO DA SILVA ressalta que "as inovações mecânicas afetam de modo particular a intensidade e o ritmo de jornada de trabalho... as inovações físico-químicas modificam as condições naturais do solo, elevando a produtividade do trabalho aplicado a esse meio de produção básico... as inovações biológicas afetam principalmente a velocidade de rotação do capital adiantado ao processo produtivo, através da redução do período de produção". $(1980, p, 41)$ 
3. CUSTOSE RENDIMENTO LIQUIDO

3.1. Produtores integrados com a indústria de processamento.

SORJ, POMPERMAYER e CORADINI (1982), trabalhando com os produtores avicolas integrados aos frigorificos em Santa Catarina, enfa tizam que o complexo agroindustrial seria o determinante básico do processo produtivo de setores crescentes da agricultura brasileira.

A moderna tecnologia empregada no setor avícola, caracterizada principalmente pelo controle genético, confinamento, além da regulação alimentar, teria transformado o produtor avícola tradicional.

As atividades que eram anteriormente realizadas no interior da empresa rural são transferidas para o ãmbito da indüstria de transformação. Uma indicação desse fenômeno seria o fato de que no pre ço final do frango, em 1976, o custo da mão-de-obra na granja de 12.000 frangos representava somente $1,5 \%$ que, acrescidos a $2,35 \%$ da prévidên cia, somavam um total de $3,85 \%$ dos custos totais. A adição do custo da mão-de-obra na produção da ração dá uma idéia da participação do traba

* Este percentual, citado pelos autores, parece estar elevado. Contudo, caso esteja superestimado reforça a idéia colocada no texto. 
tho ruxal no custo final do Erango. Importante lembrar que o milho insumo bảsicø da ração, é produzido pelo avicultor. Então, um câlculo a proximado, tomando-se como base para a ração que $25 \%$ de seu custo seria mão-de-obra, perfaz um total de cerca de $20 \%$ para os gastos com mão-de-obra rural. Na criação tradicional, a proporção do custo do frango cor respondente à mão-de-obra rural era certanente maior.

A mão-de-obra utilizada é basicamente familiar, sendo "inclusive, parte das exigências das empresas integradoras". Particular mente, "a Sadia não trabalha com proprietārios absenteístas... A familia è que deve trabalhar no aviärio, porque a Sadia não quer peão, porque o peão não tem o capricho pela produção" (p. 38, 41).

0 trabalho não esclarece se o produtor familiar de fran go de corte em Santa Catarina cultiva ou não lavouras de subsistência bora em algumas passagens seja mencionada a existência de outros cultivos.

Quanto à base técnica de produção, a pesquisa assinala que a avicultura utiliza modernas técnicas de produção, åo passo que as produções complementares apresentam um baixo grau de mecanização(p.38).

De acordo com os autores, "Nas relações de compra e venda entre produtor integrado e empresa integradora, por definição,não existe mercado opcional e, portanto, os preços são estabelecidos admiris trativamente" (p. 79). A definição desses preços se efetua através de pressões das associações das indüstrias de transformação e dos produtores de frango de corte junto ao Estado que estabelece "preços minimos 
elaborados a partir de cálculos oficiais e sempre 'negociando' com os agentes envolvidos". (p.79). Vale lembrar, entretanto, a assimetria das relações presentes entre os agentes envolvidos, dada pelo grande porte das empresas agroindustriais quando confrontado com um grande contingen te de pequenos produtores.

A pesquisa dos autores se baseia em entrevistas de campo com os produtores e dados da pesquisa realizada pelo CEBRAE/CEAG relativos.a 1977 e 1978 em Santa Catarina, basicamente junto a produtores integrados à Sadia e Perdigão. Uma anālise da estrutura de custos do produtor rural, levando-se em conta a cultura que compõe um conjunto com a avicultura, o milho na maioria dos casos, carece de naiores informações, já que os dados citados se referem somente ao frango de corte. De acordo com os autores, "na produção de aves em Santa Catarina, em 1978, 85\% dos custos eram constituidos por pintos, rações e concentrados adquiridos das empresas integradoras" (p.39).

Afirram que, tento em vista que o valor das vendas $\bar{e}$ menor que os custos mêdios, estima-se que essescustos constituem cerca de $90 \%$ do valor da produção dessa atividade. Indicando-se os custos totais por $C$ e o valor de venda da produção por $P$, de acordo com as informações de SORJ et alii (p. 39), tem-se que

$$
\begin{gathered}
0,85 \mathrm{C}=0,90 \mathrm{P} \\
\text { ou } \\
\mathrm{P}=0,944 \mathrm{C},
\end{gathered}
$$


isto ë, o valor obtido pela produção corresponde a apenas $94,4 \%$ dos custos totais. Portanto, hä um prejuizo que corresponde a $5,6 \%$ dos custos totais, Segundo os autores, 5,5\% correspondiam à mão-de-obra e depreciação. Os demais custos perfazem $94,5 \%$ do total. Verifica-se, portanto, que o valor recebido pelo produtor não cobre nem mesmo esses outros custos: exçusive mão-de-obra e depreciação.

Como o produtor avícola, segundo os autores, não inclui em seus cálculos os custos com mão-de-obra, depreciação, energia elétrica, gás e despesas financeiras, acredita que a atividade é lucrativa, jä que recebe da empresa integradora um excedente de $94,4,-35,0=9,4 \%$.

Cabe lembrar que o valor negativo de $5,6 \%$ pode, eventua $\underline{1}$ mente, ser menor, se as despesas, a nivel de propriedade, com deprecia ção, energia elétrica e financeiras foram alocadas totalmente à ativida de avícola.

Porém, quanto ao milho e/ou outras culturas as observações destacam dois aspectos:1) a exigenncia de plantio e venda desse produto à empresa integradora: "em seu estágio avançado, ə. empresa exige a produção de milho e outros componentes da ração com os quais a indústria integradora produz a ração, que fornece aos produtores integrados... o qual (milho)* será vendido em sua quase totalidade à empresa"; $(p .34,42) ; 2)$ o caráter compensatörio dessa cultura: "a produção do milho tem a função primordial de gerar excedentes na propriedade rural. Dado que a atividade integrada não a presenta resultados positivos, provavelmente estará havendo transferência de excedente do milho para esta ültima" (p. 42).

* Observação entre parēntesis minha (PMM). 
Assim, a anälise do trabalho permite tres conclusões:

a criação de frango apresenta renda liquida negativa; b) a cultura de milho apresenta renda líquida positiva $e$ ) as duas explorações são integradas a agroindūstria. Esta ültima conclusão não é enfatizada pelos autores. Trata-se de destacar que a atividade agricola integrada envolve o conjunto das duas atividades.

$$
\text { Mas ainda, os autores ressaltam que a propriedade rural }
$$
apresenta um resultado geral positivo. Para isso afirman que "A impor tância da produção de milho e outros produtos estaria en sua contribuição para a fonnação do excedente rural" (p. 42). Então, existe un excedente proveniente das atividades rurais no seu conjunto. Os autores cita dos consideram que a propriedade como un todo obtém rendimento líquido positivo apesar do prejuízo da atividade avícola (de 5,6\% dos custos totais).

Nestas circunstâncias áfirmar que a articulação com a agroindústria não leva a lucro, considerando-se somente a avicultura ë incorreto, jä que na articulação como um todo não é isso que ocorre. Por outro lado, somente com a anälise das estruturas de custo do milho e dos outros produtos é que se pode afirmar qual o valor real do resultado na atividade avicola, pois os gastos comuns podem estar indevidamente alo cados anenas à criação de frang̣os de corte. 
Qualquer que seja a alternativa, no entanto, pode-se

auestionar

a afirmativa, feita pelos autores, de que

"o produtor rural tem ainda contra si um fator que the impõe a imobilidade para sair do esquema contratual e a dependência que the criam as instala cões agrícolas" (p.64). Na realidade, o produtor agrícola obtem lucros na atividade integrada e, por isso, não tem interesse em mudar de atividade.

NEVES (1981) elabora um estudo de caso com os fornecedores de cana na região de Campos - RJ. A autora mostra as formas de articulação desses produtores com a usina (indústria de processamento), as quais implicam a reordenação das relações internas à unidade de produção familiar.

A mão-de-obra familiax é o elemento produtivo bäsico des ses produtores, sendo também responsävel pelas tarefas da lavoura de sub sistēncia e criação de gado. Eventualmente, a força de trabalho familiar è ahugada para trabalho nas propriedades maiores, que utilizam mão-de-obra assalariada. 
Os pequenos lavradores estudados por NEVES não possuem a propriedade de instrumentos mecanizados, mas sim a sua posse, através do aluguel desses equipamentos pertencentes aos médios lavradores e plan tadores de cana. 0 aluguel desses meios de produçăo permite, "que todos eles se beneficiem e possam atualizar o padrão técnico de produção impos to" (p. 31). Porém, mesmo a utilização desses instrumentos é 1imitada às fases de preparo do solo e semeadura, pois as áreas intersticiais são ocupadas por cultivos de subsistência como milho, feijão, abóbora, cuja produção excedente é. destinada ao mercado.

O preço da cana è fixado pelo IAA, a partir de decisões tomadas no Conselho Monetário Nacional. "O preço da cana não é calculado em termos dos custos dos fatores de produção", mas sim estabelecido em decorrência do preço do açúcar. Embora a definição do preço da cana atual mente não seja feita no IAA, "os fornecedores reconhecem que, nessa ins.. tituição, eles tem uma participação mais efetiva e melhor representação a nivel de voz e voto, podendo, em determinadas conjunturas, ter seus interesses e pretensões reconhecidos ou, em parte, respeitados". (p.203).

A pesquisa, pelo menos na publicação consultada, não uti 1iza dados de custo dos produtores. Através de cálculos efetuados com ba se na quantidade de cana entregue por produtor à usina no ano de 1978 , $\therefore$ aśsim como nos preços da cana em vigor em janeiro de 1978, a autora con segue uma estimativa da receita do produtor que, comparada com o salário mínimo vigente na época, fundamenta a afirmação de que "boa parte dos pequenos fornecedores não consegue atingir nem o salário mínimo vi- 
gente como rendimento líquido mensal oferecido pela produção de can a... - tabelamento do preço da cana só garante parte da reprodução simples do processo produtivo" (p. 101, 102). A cana é o cultivo principal, uma vez que a alocação dos fatores de produção disponiveis é feita prioritariamente para a cana, sendo o restante desses fatores alocados em outros culicivos e/ou criações.

Em diversos momentos, a autora faz observações quanto à eficiência na alocação de fatores pelos fornecedores de cana: "alguns produtos complementañ a utilização de terras intersticiais à plantação de cana e o uso de força de trabalho näo apropriada nessa atividade"; (p. 7.8) "cana e gado formam um binômio de complementariedade do processo produtivo... o gado possibilita a utilização completa da cana, certo con trole sobre o consumo cotidiano, na medida em que assegura um rendimento diārio pela venda do 1eite" (p. 124).

Uma consequência dessa eficiência na alocação dos fato-res de produção que não é explorada por NEVES, ainda que notada, é que os custos de produção da cana evidentemente são menores do que na situa ção de se produzir somente cana. Nessa situação, o custo da cana está sendo claramente aumentado.

Apenas se a autora trabalhasse com os custos da produção da cana-de-açucar é que obteria dddos para respaldar a afirmativa de que "o tabelamento do preço de cana só garante parte de reprodução simples do processo produtivo". 
Acredita-se que se Posse alocado aos custos somente a quantidade de fatores realmente utilizados no cultivo da cana, não seria constatada a existência de prejuizo:

O trabalho de SANTOS (1978) mostra o caso dos pequenos produtores de uva da região de Bento Gonçalves - RS, localizados no baị ro rural de São Pedro, e dedicados à combinação da produção para a subsis tência com a mercantil.

A motobomba é o instrumento mais mecanizado existente na unidade produtiva, indicando assim uma participação bem maior do trabalho em relação aos insumos modernos no processo de trabaiho. Defensivos, corretivos e fertilizantes são utilizados apenas na cultura comercial.

o trabalho familiar é a condição básica desses produtores no sentido de que todas as tarefas da propriedade são por eles efetuadas. A conjugação das disponibilidades de mão-de-obra familiar com as exigências produtivas é que vai provocar outras relações de produção, como mutirão e troca de dias. Entretanto, uma utilização complementar do trabalho familiar acontece nas épocas de relativa ociosidade no ciclo produtivo quando um ou mais membros da família saem para se empregar 
nas cercanias ou na cidade, visando com isso melhorar a renda familiar.

A anälise do custo industrial do vinho, com base em 1971, mostra que a matéria prima uva comparece com atē $73,8 \%$ dos custos industriais, mas com a inclusão dos custos comerciais a uva represent a ate $54,3 \%$ dos custos totais, indicando que a rentabilidade desse setor vai depender, basicamente, das condições de compra da matéria-prima uva. Nessa época, regisțra-se uma intensificação da concorrência originada a partir da entrada de novas empresas no mercado, resultando em uma tendência para garantir o fornecimento da matéria-prima produzida pelos pequenos produtores. As relações dos produtores com a indústria deixam de acontecer pelo esquema vigente que era o da 'freguesia', sendo crescentemente substituido pelo contrato de compra e venda.

Una das cláusulas desse contrato prevê que a indústria vinícola "se compromete a pagar o preço numca inferior ao da Tabela oficial do Estado que anualmente for estabelecida" (p. 96). Esse preço é negociado pelos produtores vinicolas e industriais e mediado pela Secretaria de" Agricultura. Sugestões são apresentadas por ambos os setores, acrescida de um estudo de custo da produção de uvas de diversas variedades preparado por um orgão técnico.. O autor revela, porém, que o produtor vinícola percebe a elaboração da tabela como sendo feita pelos industriais e somente referendada pela Secretaria.

Contudo, na prática, as indústrias recorrem a outros expedientes como as burlas na classificação das unas. Mediante o retardo no recebimento, seja na porta da fábrica, seja na parreira via limitação da cota diária a ser entregue pe 
1o produtor, a fermentação da uva transforma o açūcar em ālcool, implicando queda na graduação glucométrica abaixo do mínimo estipulado na tabela de preços.

A questão que se coloca, porēm, é se essa uva de graduação inferior impede ou prejudic a a fabricação do vinho, justificando, assim, um menor preço pago ao fornecedor. A observação das fases de pro cessamento mostra a necessidade da correção do mosto devido a variações do clima local, e, por conseguinte, as deficiências na qualidade da uva como matéria-prima podem ser superadas por operações técnicas jā previstas no ciclo normal de processamento. Assim, é vantajoso comprar uvas com graduação inferior, pois o desconto no preço excederá o custo da correção.

Na parte de rendimentos, será utilizada uma composição de dois quadros da pesquisa, lembrando que "os dados apresentados referem-se apenas à produção mercantil (uva), não tendo sido incluídos dados referentes à produção para subsistência" (p.26).

0 quadro a seguir mostra que o rendimento líquido apurado tem que superar o custo da mão-de-obra alocada na uva para que o pro dutor obtenha lucro líquido (poupança) na atividade integrada com a indüstria vinícola. Mas, como o quadro só diz respeito à exploração da uva, verifica-se que toda a mão-de-obra familiar disponível está totalmente alocada nessa cultura, o que não é correto.

A pesquisa mostra que parte da produção para subsistência é comercializada para garantir a compra de outros produtos não cul- 


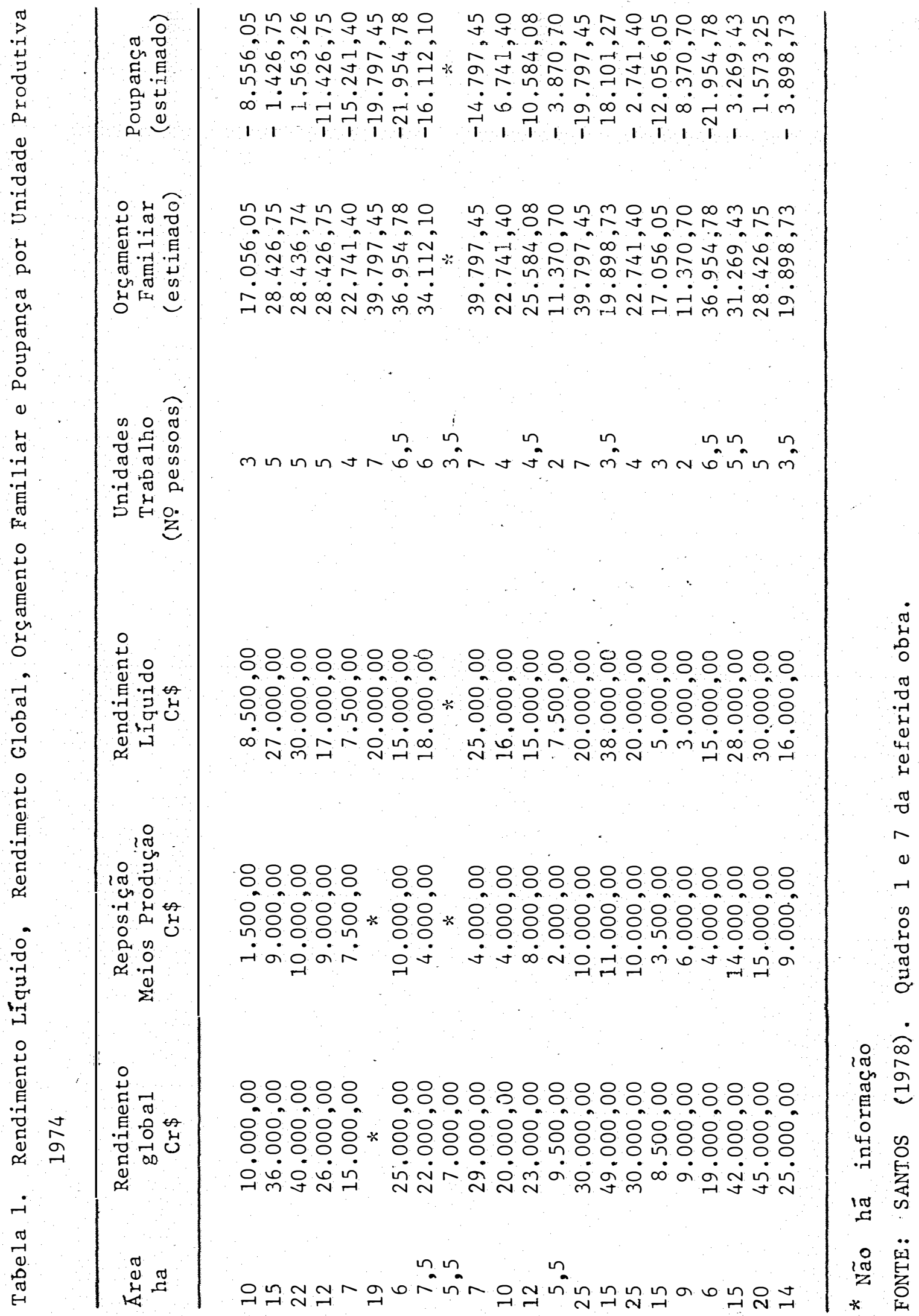


tivados na propriedade. Se é assim, a mão-de-obra alocada nos cultivos de subsistência tem que ser descontada da mão-de-obra total disponível na unidade produtiva. A análise da coluna poupança mostra que mesmo com toda mão-de-obra alocad a na uva, há três produtores para os quais esta é positiva. Assim, qualquer alocação de mão-de-oḅra que se faça aos cultivos de subsistência implicarā.. aumento do nümero de produtores com "pou pança" positiva. Este fato confirma a idéia de que somente com estruturas de custos mais detalhadas é que se pode captar relações entre os cul tivos.

Por outro lado, como o autor não cita, em seu trabaliho, Indices técnicos do cultivo da uva nem dos outros cultivos e criações, torna-se difícil adotar un critério para alocação da mão-de-obra realmente utilizada no cultivo da uva. A ärea utilizada para cada cultura e criação também não é citada.

0 quadro 6 da pesquisa mostra o calendärio das tarefas agrî́colas. Porèm, a ênfase está na cultura da uva, enquanto que os outros cultivos são citados para mostrar sua existência, mas sem elementos que permitam algum critério de rateio para a mão-de-obra. Resta a possi bilidade qualitativa dos comentärios efetuados pelo autor. Segundo SANTOS, " o orçamento familiar corresponde a uma ficção: na realidade; a reprodução de força de trabalho é coberta em sua maior parte pela produção direta dos meios de vida, o que dispensa o gasto monetário com $\therefore$ a subsistência da família camponesa" (p. 66). Além disso, "parte dessa produção é comercializada - feijão, soja, leite, manteiga, queijo, cebola, le 
gumes, banha - pois constitui o produto dos fatores de produção excedentes dos que foram utilizados na subsistência". (p. 70)

Em seguida, SANTOS observa que "Assim se explica como, em vãrias situações, os camponeses de São Pedro tem dinheiro disponỉvel para adquirir instrumentos de trabatho e bens de consumo,para dar o dote das filhas, para ajudar os filhos que migram, para fazer festas, etc. Essas despesas são cobertas pela soma integral do'rendimento líquido', o qual, em razão da agricultura de subsistência, vai-se confundir efetivamente com a poupança'" (p. 66).

$\mathrm{Na}$ verdade, se o autor alocasse somente a fração de mão-de-obra utilizada no cultivo da uva chegaria, como ressalta em certos momentos, à conclusão de que o produtor de uva retem algum excedente na articulação com a agroindưstria.

A. pesquisa de FREDERICQ (1982) foi feita com os produtores de leite ligados à Nestlé no município de Três Corações-MG. O produto bạ sico (leite cru) desses produtores é enviado para a indūstria de processamento que o transforma em derivados para as camadas médias e altas da população num processo que teria deslocado, segundo a autora, a amamenta ção materna.

As agroindústrias, já de saída, contam com um preço reprí mido, uma vez que é essa mesma matéria prima que dá origem ao leite pasteurizado, cujo preço final é tabelado pelo Governo. Por um lado, essas limitações os beneficiam mas, por outro, dificultam o abastecimento regu lar de matéria prima de boa qualidade. "O aumento de produção não pode 
depender demais da aquisição pelo produtor, de insumos modernos, que ele varão seus custos e, consequentemente, o preço de venda da sua matéria-prima" (p, 127). Com esse objetivo, a empresa cria um setor de assistên cia técnica que sugere ao produtor "a necessidade de alimentação adequada para o gado produzida, na medida do possível, na própria fazenda para permitir uma economia de rações concentradas" (p. 128).

Geralmente, os produtores de leite se associam às coopera tivas regionais, que "reforçam seu poder de barganhe em fumção da grande quantidade de leite de que dispõem" (p. 135), jā que "o preço mínimo è tabelado, mas certas empresas podem preferir pagar alguns centavos a mais por litro, para garantir a manutenção do seu fornecimento" (p. 139).

No período que antecede a época da pesquisa a autora asse vera que na āre a de recebimento da Nestlé como um todo "os estabelecimen tos maiores alcançaram um nível de modernização muito alto: como se trata de una área tradicionalmente leiteira, chegaram ao longo dos anos a uma infraestrutura bastante desenvolvida. Quanto às explorações menores,fize ram mencres investimentos em instalações físicas e mäquinarias agrícólas" $(p \cdot 133)$

Quando da pesquisa, a a utora destaca que todos os produto res de leite da região se queixavam do baixo preço do leite e de sua pequena rentabilidade. De 17 produtores entrevistados, 4 declaravam que con: tinuariam produzindo leite, 2 iriam mudar de negócios mas, o que é decisi vo, 11 iriam mudar de atividade agrícola no sentido de reduzir a importân cia da produção leiteira. Nota-se,claramente,pelo comportamento de cerca de 2/3 dos produtores, uma associação entre a baixa rentabilidade do 1eite e a mudança de exploração.

Assim, houve um periodo em que us produtores acumulararn algum capital e investiram na melhoria de suas instalações, mas, a partir de algum momento, por volta de 1979, não viram vantagem na 
continuidade da produção de leite, tanto que mudaram de atividade agrícola, particularmente para o café.

Embora não se tenha condições de uma anālise mais detaThada das estruturas de custos, verificanse que os produtores continuariam se balizando principalmente pela busca do rendimento líquido positivo para a permanencia ou náo dentro de determinada linha de produção.

Os casos da literatura revisados até aqui mostram situações que privilegiam a ligação entre agroindústria e produtor agríco1a. Seja porque, nessas pesquisas, os interesses são outros, seja porque não se achou relevante, o fato é que as estruturas de custos não sao aprofundadas em grau suficiente, que permitam o entendimento das relações internas entre cultivos.

\subsection{Custos de Produtos Aprícolas}

Dada a importância do cálculo de custos para os objetivos deste estudo, far-se-ā uma revisão de trabalhos sobre custo de pro dução de alguns produtos agrícolas, tendo em vista verificar se aí são levadas em consideração as relações entre culturas complementares e, em caso positivo, como isso é feito.

Inicialmente foi feita uma anālise das estimativas de custo operacional de produção oriundas do IEA (Instituto de Economia Agrícola) para a safra $84 / 85$ onde se nota que se "considera como 
despesas diretas todo o desembolso efetuado pelo produtor na compra de sementes, no pagamento de mão-de-obra, nas operações de máquinas e implementos, nos gastos com adubos, corretivos, defensivos, embalagens e outros materiais" (p, 21). As pesquisas de campo, elaboradas periodicamente, visam captar modificações no processo produtivo, decorrentes, em geral, de alterações no nível tecnológico. Apurou-se, junto ao IEA, que não são formuladas questões relativas às ligações entre cultives, particu larmente com respeito à adubação.

o trabalho de MATSUNAGA et alii (1976) apresenta aspectos relativos à origem da metodologia de custo de prodiução (estimativa de custo operacional) que passou a ser utilizada pelo IEA desde 1972, e divulgada pela primeira vez no Prognóstico 72/73. A anālise deste trabalho mostra não existir argumentação específica a respeito da ligação entre um cultivo e seu subseqủente. Também nada consta a respeito de resíduos de adubação, embora seja notada uma observação sobre o rateio do custo de conservação de máquinas e equipamentos, bem como de gastos com combustíveis e lubrificantes. Vale ressaltar que, na estrutura de custo do milho apresentada nesse artigo constata-se que, no ano de 1975 para São Paulo, o adubo era responsāvel por praticamente $30 \%$ dos custos operacionais, isso levando-se em conta o. subsídio que era, na época, de $40 \%$.

A pesquisa de MEIRELlES (1962) tem como um dos objetivos apurar o custo de produção do tomate envarado na região de Indaiatuba, 
núcleo de colônia japonesa, uma das mais importantes zonas de produção do Estado naquela época.

A incidência de pragas obriga os agricultores a não utilizar o mesmo local dois anos consecutivos para cultivo do tomate além de que "a rotação de cultura é feita também para aproveitar os efeitos residuais de adubação do tomateiro. Assim, arrancados os restos culturais e retirado o estaqueamento, são cultivados o milho (na maior parte) ou hortaliças como beringela, pepino, quiabo, abobrinha, couve-flor e, em poucos casos, é feita a adubação verde (crotalária ou $1 a b-1 a b) "(p .49)$.

Assim, o autor capta, já em 1962, uma prática dos agricultores que visa a reduzir os custos de produção do tomate, pois o resíduo do adubo, existente no solo, será absorvido pela cultura seguinte.

Os custos de adubação ( $16 \%$ dos custos totais do tomate) são alocados totalmente ao tomate ainda que o agricultor certamente vā reduzir ou eliminar, conforme observação do autor, a adubação do milho. Se o custo do tomate fosse aliviado de uma parcela dos custos com adubação se estaria, provavelmente, mais próximo da realidade.

O trabalho de NEVES e MATSUNAGA (1969) sobre o custo do tomate rasteiro na região de Taquaritinga mostra a existência de dois sistemas de produção. Um é denominado tração animal, onde as āreas cultivadas com tomate variavam de 1 a 6 alqueires com ārea média de cultivo de 3 alq. e com ärea total média das propriedades em torno de 16 alq. Assim, em média, a ärea com tomate está 
por volta de $20 \%$ da ārea total do estabelecimento. 0 outro sistema de produção utilizava a tração motomecanizada, onde as äreas cultivadas com tomate são maiores, variando de 15 a 60 alq., com frequência maior ao redor de 27 alq. e com área média das empresas de 140 alq. Nessa situação, a relação também está por volta de $20 \%$ da ārea total. Em ambos os casos, seria de se supor que os produtores cultivassem outros produtos quer simultaneamente, quer em sequîencia ao tomate na mesma área.

A cultura do tomate é exigente em termos de adubação. Segundo dados da pesquisa, representa $30 \%$ do gasto total, somente sendo superado pelos gastos com mão-de-obra. Como o agricultor coloca menos adu bo para o cultivo subseqüente em função de resíduos decorrentes da cul tura do tomate, há necessidade em se reduzir a alocação dos custos de adubação no tomate, se se quiser obter um custo mais próximo da realidade Entretanto, no trabalho de NEVES e MATSUNAGA (1969) todo o custo da adubação foi incluido no custo de produção do tomate.

Dessa forma, nas pesquisas cujo objetivo específico é apurar custos de produção se verifica que não é dado destaque às relações entre cultivos. 
4. OS PRODUTORES DE TOMATE PARA INDUSTRIA

4.1. Medida do Rendimento Liquido e Dados Utilizados

0 rendimento líquido proporcionado ao produtor pela exp lo ração de tomate para indústria será calculado da seguinte forma: se da receita bruta de tomate vendido à indústria forem subtraídos os custos de produção, a diferença restante será o rendimento líquido dessa cultura. Rendimento Líquido = Receita Bruta - (Despesa Desgaste + Despesa Insum + + Despesa Força Trabalho)

$$
R_{L}=R_{B}-\left(D_{D}+D_{I}+D_{F T}\right)
$$

Ocorre que a cultura do tomate, para minimizar a atuação de pragas, requer que a área para cultivo não tenha sido utilizada nos ultimos 2 ou 3 anos para cultivo de tomate. Portanto, a exigência que se coloca para o tomate é que seja uma cultura itinerante. Consequlentemente, como veremos mais adiante, nos dados colhidos, o produtor de tomate é 
arrendatário e, sendo assim, o preço do arrendamento, que pode ser toma do como o valor monetário da renda da terra, é um custo explícito para esse produtor.

As despesas com juros constituem outro elemento incluído no trabalho excedente gerado na produção de tomate. Estes juros são uma fração do lucro que è paga pelo arrendatärio ao banco. Analo ganente, fazem parte do custo para o produtor de tomate. Assim,

Rendimento Líquido Produtor Tomate = Rendimento Líquido menos (Custo Arrendamento + Custo dos Juros)

ou

$\mathrm{RL}_{\mathrm{P}}=\mathrm{RI}_{\mathrm{s}}-\left(\mathrm{C}_{\mathrm{A}}+\mathrm{C}_{\mathrm{J}}\right)$

Para medir a rentabilidade líquida dos produtores de tomate para indústria, utilizaram-se os dados de questionärios aplícados durante agosto e setembro de 1979, pelo Instituto de Economia Agrícola (IEA) - Secretaria da Agri cultura.

0 principal objetivo da pesquisa foi elaborar uma matriz de coeficientes técnicos para servir de subsídio à determinação do preço a ser pago durante determinada safra de tomate. Esse preço 
é definido pelo Comitê de Agrcindústria, formado pelos representantes das organizações dos produtores, das indústrias de processamento, além de representantes do IEA.

Essa definição do preço que orienta a elaboração de contratos de fornecimento entre produtores e indústria, segundo informaçöes dos responsáveis pela pesquisa, se ressentia da falta de indices técnicos representativos da cultura do tomate para indūstria. Havia muita discrepância com respeito, por exemplo, à conceituação do que seria um nível de produtividade aceitável para o tomate rasteiro.

Levantadas as regiões produtoras do Estado de São Pau1o, selecionaram-se as regiões mais importantes, em termos de volume de produção. Este critério definiu as regiões de Araçatuba, Presidente Prudente, Ribeirão Preto, São José do Rio Preto. A Tabela 2 ilus tra a produção, ārea e produtividade por região do Estado de São Paulo, para o tomate rasteiro, em 1979.

Tabela 2. Produção, Area e Produtividade por Região, Estado de São Paulo, Safra de 1979

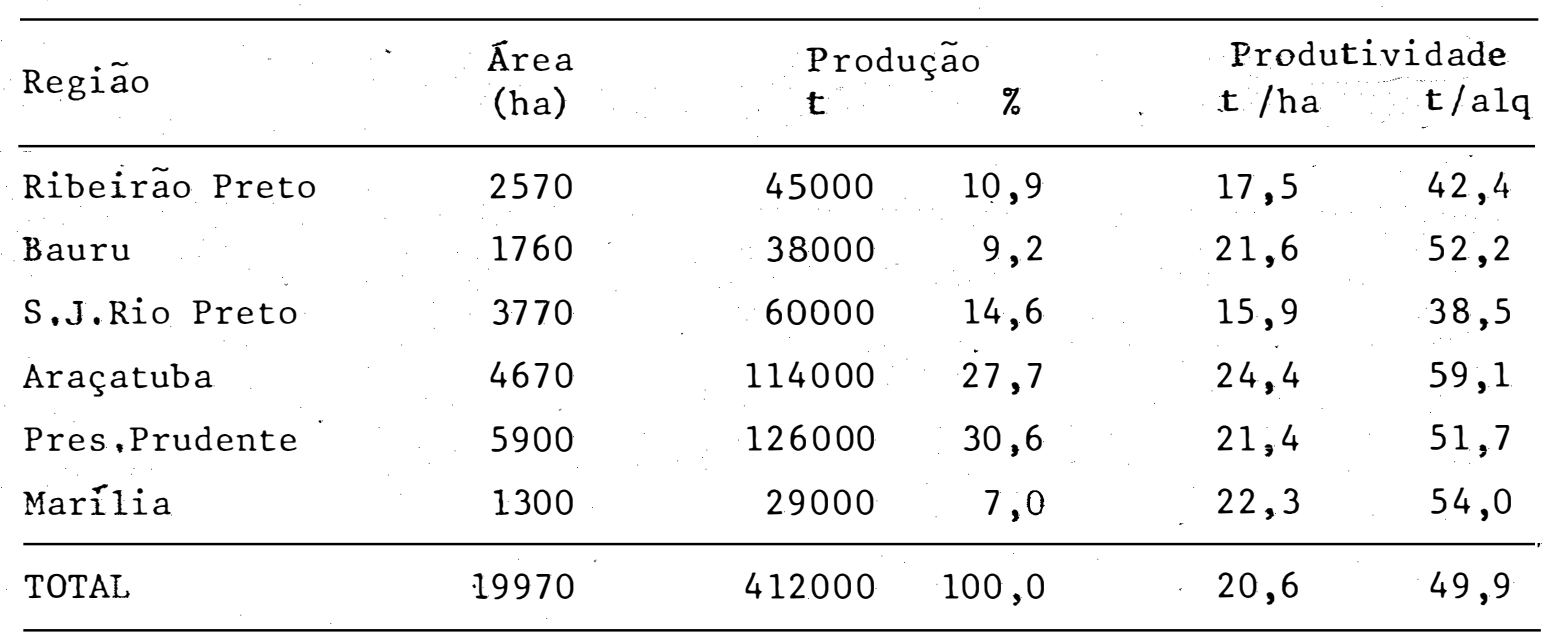

FONTE: Instituto Economia Agrícola 
Após elaboração da relação de produtores de tomate para indūs-tria, conhecidos pelo agrônomo da Casa da Agricultura de cada região,procurouse definir o tamanho da amostra, que foi de 115 produtores. Dentre os 115 pro dutores, buscou-se uma divisão proporcional ao número de produtores de cada região, segundo o estrato de ärea plantada com tomate ao qual pertencia. No inicio da pesquisa, efetuoumse um ajuste, visando melhorar a representativida de por estrato, em. Eunção das informações obtidas nas primeiras pesquisas. Como os produtores entrevistados representavam uma proporção aproximadamente constante, por estrato de ārea, dos produtores que forneciam à indústria, node-se afirnar que a amostra estratificada era aproximadamente proporcional.

A Tabela 3 mostra o número de produtores pesquisados por região segundo o extrato de ärea e segundo a utilização de irrigação

Tabela 3 .. Distribuição das Propriedades Entrevistadas por Região, por Ārea e por Tecnoloria Utilizaada (com Irriogaça e sem Irrigacão), 1979.

\begin{tabular}{|c|c|c|c|c|c|c|c|c|c|c|c|}
\hline \multirow{2}{*}{ Estrato } & \multirow[b]{2}{*}{$\begin{array}{c}\text { Ārea } \\
\text { (ha) }\end{array}$} & \multicolumn{2}{|c|}{ S.J.R.Preto } & \multicolumn{2}{|c|}{ Rib.Preto } & \multicolumn{2}{|c|}{ Araçatuba } & \multicolumn{2}{|c|}{ P.Prud. } & \multicolumn{2}{|c|}{ Tota1 } \\
\hline & & $\begin{array}{c}\text { No } \\
\text { Prop! }\end{array}$ & $\begin{array}{l}\text { Com } \\
\text { Irr. }\end{array}$ & $\begin{array}{c}\text { NQ } \\
\text { Prop. }\end{array}$ & $\begin{array}{l}\text { com } \\
\text { Irr. }\end{array}$ & $\begin{array}{c}\text { No } \\
\text { Prot. }\end{array}$ & $\begin{array}{l}\text { com } \\
\text { Irr. }\end{array}$ & $\begin{array}{c}\text { No } \\
\text { Prop. }\end{array}$ & $\begin{array}{l}\text { com } \\
\text { Irr. }\end{array}$ & $\begin{array}{c}\text { No } \\
\text { Prop. }\end{array}$ & $\begin{array}{l}\text { com } \\
\text { Irr. }\end{array}$ \\
\hline I & $<12$ & 5 & 3 & 2 & 1 & 4 & 1 & 2 & 0 & 13 & 4 \\
\hline II & $12-50$ & 2 & 1 & 12 & 6 & 26 & 14 & 28 & 8 & 68 & 29 \\
\hline III & $>50$ & 4 & 0 & 9 & 6 & 12 & 10 & 9 & 9 & 34 & 29 \\
\hline Tota1 & & 11 & 4 & 23 & 13 & 42 & 25 & 39 & 17 & 115 & 62 \\
\hline
\end{tabular}

FONTE: Pesquisa IEA.

Notarse uma predominância de produtores de tomate não irrigado nos estratos I e II, ocorrendo o inverso no estrato III. 
A produção de tomate irrigado neste estrato, se bem que distribuída entre todas regiões, se acentua nas regiões mais novas, em termos de produção de tomate para indústria, Araçatuba e Presidente Prudente.

Dos 115 questionários aplicados, 6 foram anulados. Cinco dos questionários anulados referiam-se a produtores de Ribeirão Pre to (4 irrigados e 1 não irrigado) e o sexto era relativo a um produtor de tomate irrigado em Presidente Prudente. Assim, o número de questio närios utilizados foi de 109.

Como o nümero total de questionärios, bem como o total de regiões fosse elevado em termos do tempo disponível para uma anālise mais abrangente, optou-se por escolher uma região e concentrar-se nela, em termos de análise dos objetivos a que se propôs.

Com essa restrição em mente, delinearam-se alguns pon tos básicos a serem atendidos pela região a ser escolhida.

- região importante em volume de produção;

- região caracterizada pela predominância de produção de tomate irrigado, pois sempre é bom lembrar que, para a indústria, hả interesse em que o produtor agrícola 
utilize a irrigação, Com essa tecnologia se minimiza a influência do fator climático (falta de chuvas) no fornecimento de sua matéria prima.

A primeira diretiva jā excluía as regiões de São José do Rio Preto e Ribeirão Preto (regiões tradicionais), uma vez que as participaçóes dessas regiões na produção do Estado erañ de 14,6 e 10,9\%, respectivamente. As regiões restantes, Araçatuba e Presidente Prudente (regiões novas) correspondiam 27,7 e $30,6 \%$, respectivamente.

A segunda diretiva deveria decidir a região a ser esco 1hida. BEMELMANS et alii (1980, p. 37) observam que, na época, "áreas cultivadas com tomate que não fazem uso de irrigação estão cedendo lugar àquelas que a utilizam". As regiões de Araçatuba e Presidente Pru dente contrastam, nesse item, pois a primeira conta com $60 \%$ de produtores de tomate irrigado, enquanto a segunda conta com $47 \%$ de produtores naquela condição. O percentual apresentado pela região de Araçatuba é significativo e, por esse motivo, determina sua escolha como região para analisar-se as ligações com a agroindústria.

BEMELMANS et alii (1980, p.43) tambēm afirmam que "Em Presidente Prudente, os tomaticultores obtiveram rendimentos médios superiores aos de Araçatuba, com quantidades inferiores de fertilizantes... em Araçatuba estão sendo usadas quantidades superiores (à média), notadamente no que se refere a fungicidas". Sendo assim, 
acredita-se que os resultados apurados para a região de Araçatuba possam ser estendidos nara a região de Presidente Prudente, naquele ano.

\subsection{Cálculo e Análise do Rendimento Líquido.}

A consulta às atas dereuniões do Comitê de Agroindústria anteriores à ëpoca da pesquisa mostra que havia pressão dos produtores de tomate quanto ao preço definido que era de $\operatorname{Cr} \$ 1,75 / \mathrm{kg}$, alegando que este valor não cobria os custos: Como os dados da pesquisa assinalavam preço de Cr\$1,75 procurou-se o responsável do IEA pela pesquisa, visando checar este valor. Após confirmar aquele preço, como apurado nas pesquisas, lembrou que, inclusive, a safra de 1979 foi superior à média normal, rejeitando a idéia de que os produtores tivessem conseguido um preço superior àquele jà estabelecido.

As Tabelas 4 e 5 apresentam os dados para cada produtor, sendo uma tabela para os produtores de tomate irrigado e a outra para os produtores de tomate não irrigado.

A área média plantada com tomate rasteiro foi calculada levando em conta todos os 25 produtores, não importando para o seu cálculo se o produtor arrendou, ou cultivou em terra própria, ou ainda combinou as duas alternativas. 


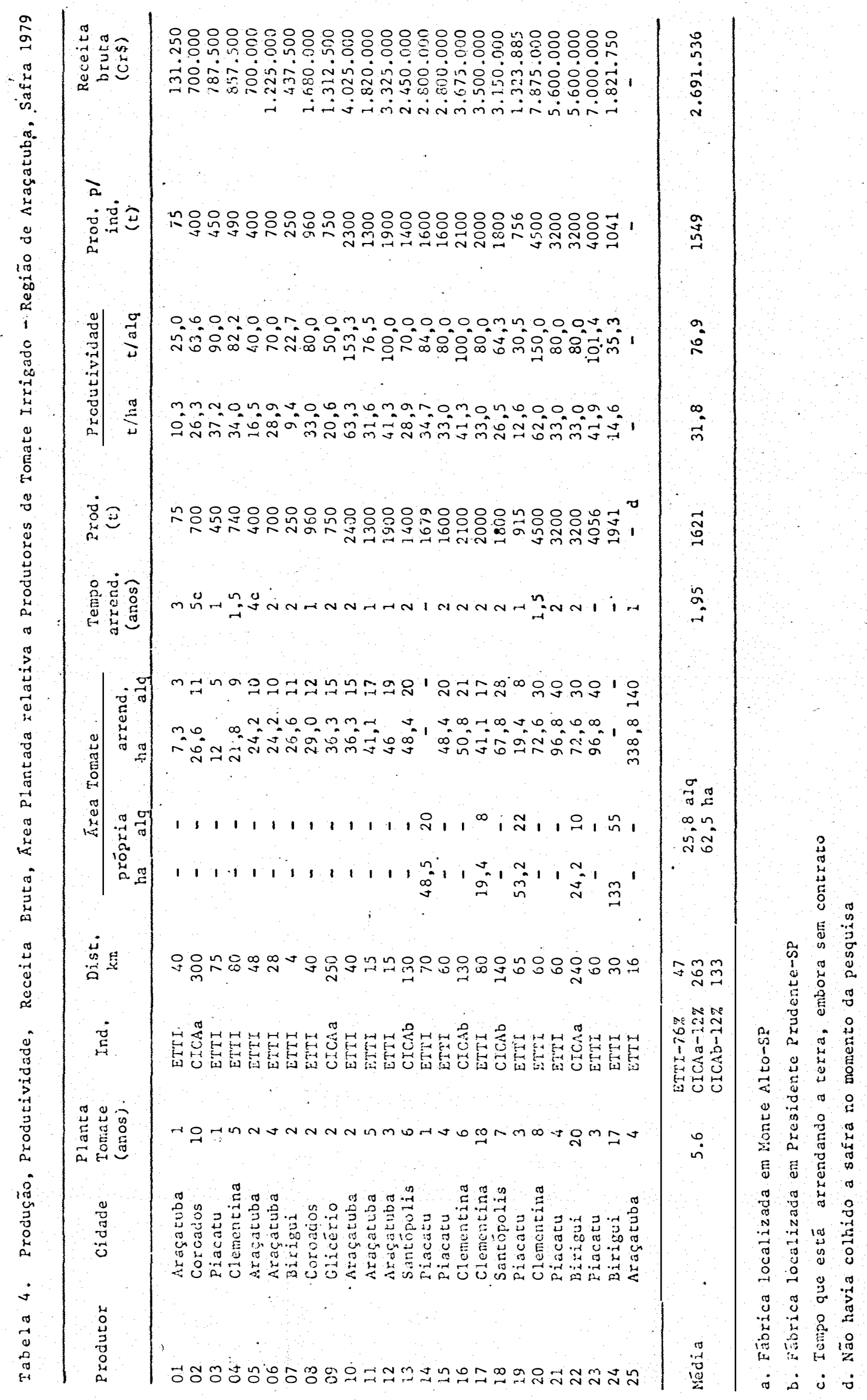




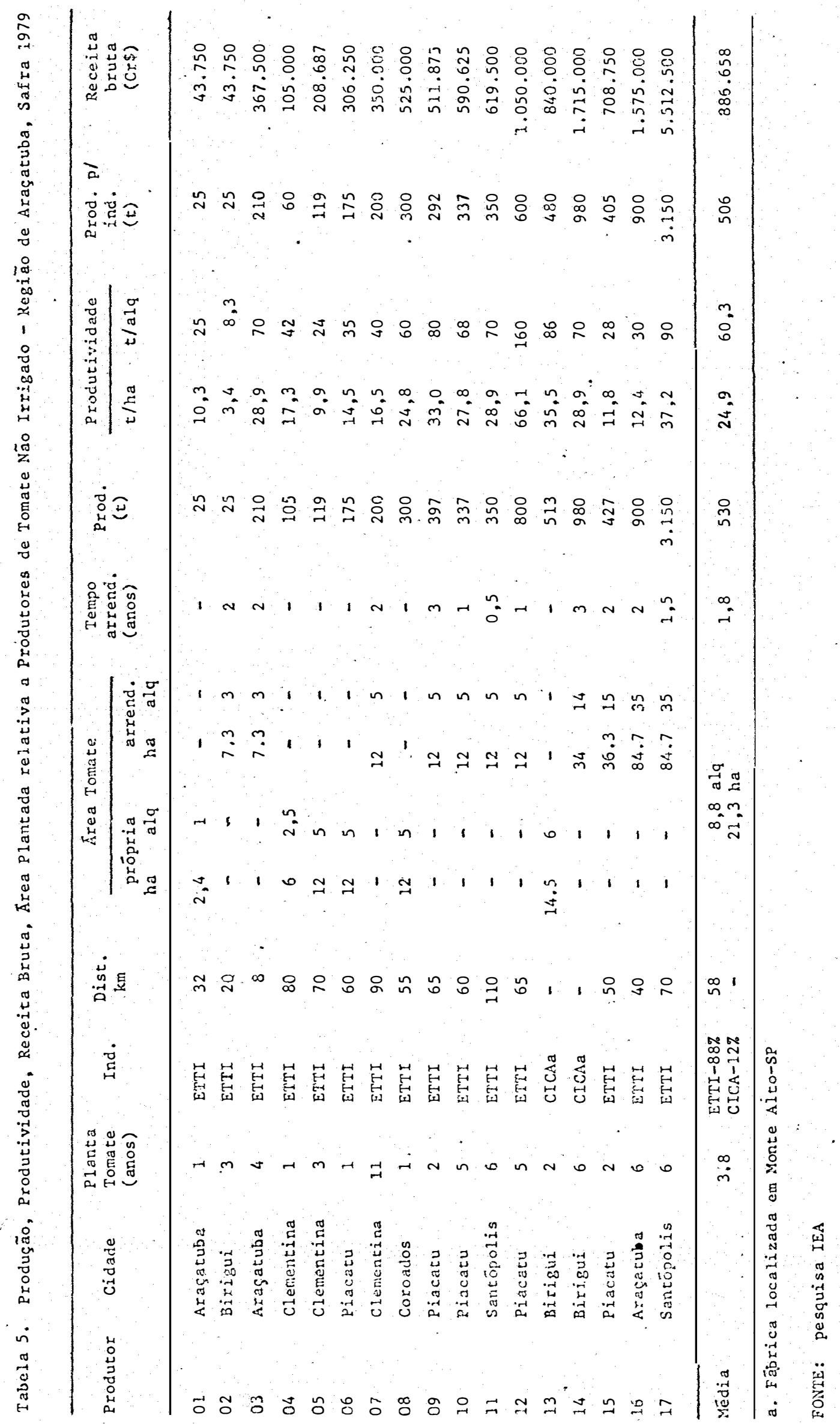


0 produtor núme ro 25 sèrä eliminado da amostra, para os efeitos deste trabalho, pois não se conseguiu os itens produção, produtivi dade e receita, dado que, por ocasião da entrevista, ele ainda não havia feito a colheita.

A receita bruta com tomate vendido à indústria foi calculada multiplicando-se a quantidade realmente vendida à indústria por 1,75 $\operatorname{Cr} \$ / \mathrm{kg}$, conforme dados da pesquisa. Constatou-se que cerca de $30 \%$ dos pro dutores de tomate irrigado e não irrigado comercializavam parte de sua safra, $18 \%$ em média, at.ravés da venda das colheitas iniciais para o mercado de tomate de mesa. Como os custos não for am separados conforme o destino do tomate, o custo do tomate de mesa foi totalmente alocado ao custo do tomate vendido para as indústrias. Por conseqúléncia, o rendimento líquido proveniente do tomate vendido à indústria está subestimado.

As despesas de um produtor agrícola são, via de regra, distribuidas no tempo, ou seja, não ocorrem todas no mesmo instante. Os gastos com o plantio não ocorrem juntamente com os gastos da colheita, por exemplo. Desta forma, un cálculo que pretenda ser realista deve tentar localizar no tempo as diversas despesas do agricultor e, através da utilização de um índice de variação dos preços, atualizar os valores para um mo* mento considerado conveniente.

Entretanto, não há no questionārio informação sobre a data em que é efetuada cada despesa. Assim, admitiu-se, de acordo com os pesquisadores do IEA, que o ciclo de produção era, para todos os produtores, o seguinte :

- abril

- preparo e plantio

- maio, junho, inỉcio de julho - tratos culturais

- fim de julho, início de aģosto - colheita 
Definiram-se como despesas importantes a serem distribuídas no tempo os desembolsos monetários que garantem a sequéncia do ciclo produtivo, ou seja, os gastos com mão-de-obra, materiais, māquinas e equipamentos. A receita bruta auferida pelo produtor agrícola também foi distribuída no tempo, uma vez que o prazo de pagamento utilizado era de 60/90 dias, conforme informação do IEA.

Como as três parcelas do crédito rural eram liberadas em 30, 60 dias e a última na colheita, supôs-se, para simplificar os cálcu los, que o crédito rural era recebido no mesmo momento em que o produtor efetuava os pagamentos. Chamaremos de saldo às diferenças entre respecti vas parcelas e desembolsos.

As parcelas do crëdito $\mathrm{r}$ ural e os desembolsos do produtor foram calculados tendo como base a matriz de coeficientes técnicos da região de Araçatuba, conforme obtida na pesquisa. Assim, o valor do crédito, quando solicitado, e das despesas foi partido em três parcelas equivalentes a $63 \%, 24,5 \%$ e $12,5 \%$ para os produtores de tomate irrigado e $69 \%, 16 \%$ e $15 \%$ para os produtores de tomate não irrigado.

Una consulta feita ao DERAL. (Departamento de Crédito Rural) do BANEȘA-SP apontou que a liberação das parcelas para o tomate ras teiro segue uma proporção de $69 \%, 18 \%, 13 \%$, embora haja diversos fatores como època, banco, agéncia, que influem nessa divisão. Considerou-se, em termos gerais, uma variação razoável a faixa de 60 a 70\% para a 1ạ parce la, contrabalançada, em sua maior parte, pela 2 a parcela. 
Desse modo, o critério adotado com base na matriz de coeficientes técnicos do IEA enquadra-se no esquema genérico de partição e será utilizado no presente trabalho.

Para atualização dos valores monetários adotou-se o Indice Geral de Preços - IGP (Coluna 2), da FGV, válido para o ano de 1979.

A Figura 2 mostra o esquema adotado.

Figura 2. Fluxo das Despesas do Produtor Agrícola

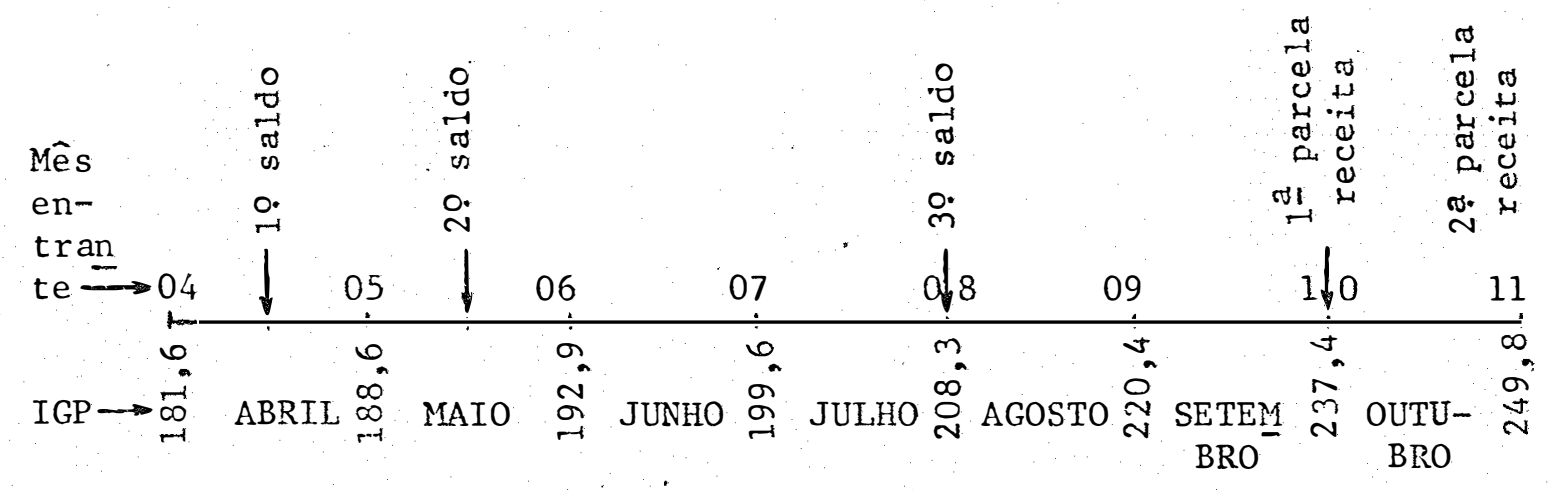

Os coeficientes de atualização para o 19 saldo $\left(C_{1}\right), \quad 29$ saldo $\left(C_{2}\right)$, 39 saldo $\left(C_{3}\right)$ e 1 a parcela de receita $\left(C_{4}\right)$, são calculados da seguinte forma: 


$$
\begin{aligned}
& C_{1}=\frac{\mathrm{IGP}_{10}}{\frac{\mathrm{IGP}_{3}+\mathrm{IGP}_{4}}{2}}=\frac{249,8}{\frac{181,6+188,6}{2}}=1,3499054 \\
& \mathrm{C}_{2}=\frac{\mathrm{IGP}_{10}}{\frac{\mathrm{IGP}_{4}+\mathrm{IGP}_{5}}{2}}=\frac{249,8}{\frac{188,6+192,9}{2}}=1,3099109 \\
& \mathrm{C}_{3}=\frac{\mathrm{IGP}_{10}}{\mathrm{IGP}_{7}}=\frac{249,8}{208,3}=1,1992318 \\
& \mathrm{C}_{4}=\frac{\mathrm{IGP}_{10}}{\mathrm{IGP}_{9}}=\frac{249,8}{237,4}=1,0522325
\end{aligned}
$$

As tabelas 6 e 7 destacam os valores no instante em que acontecem e o seu valor atualizado para outubro de 1979 , atra vēs do IGP.*

Com os valores dos saldos corrigidos, tem-se os dados todos referidos à mesma data $(01 / 11)$. Agora, podem-se efetuar cálculos para apurar o rendimento líquido para cada produtor.

* Os valores em cruzeiros foram calculados a partir dos coeficientes tēc nicos apurados na pesquisa, multiplicados pelos custos por dia de serviegos publicados nelo IEA em Informações Económicas de 07.79. 


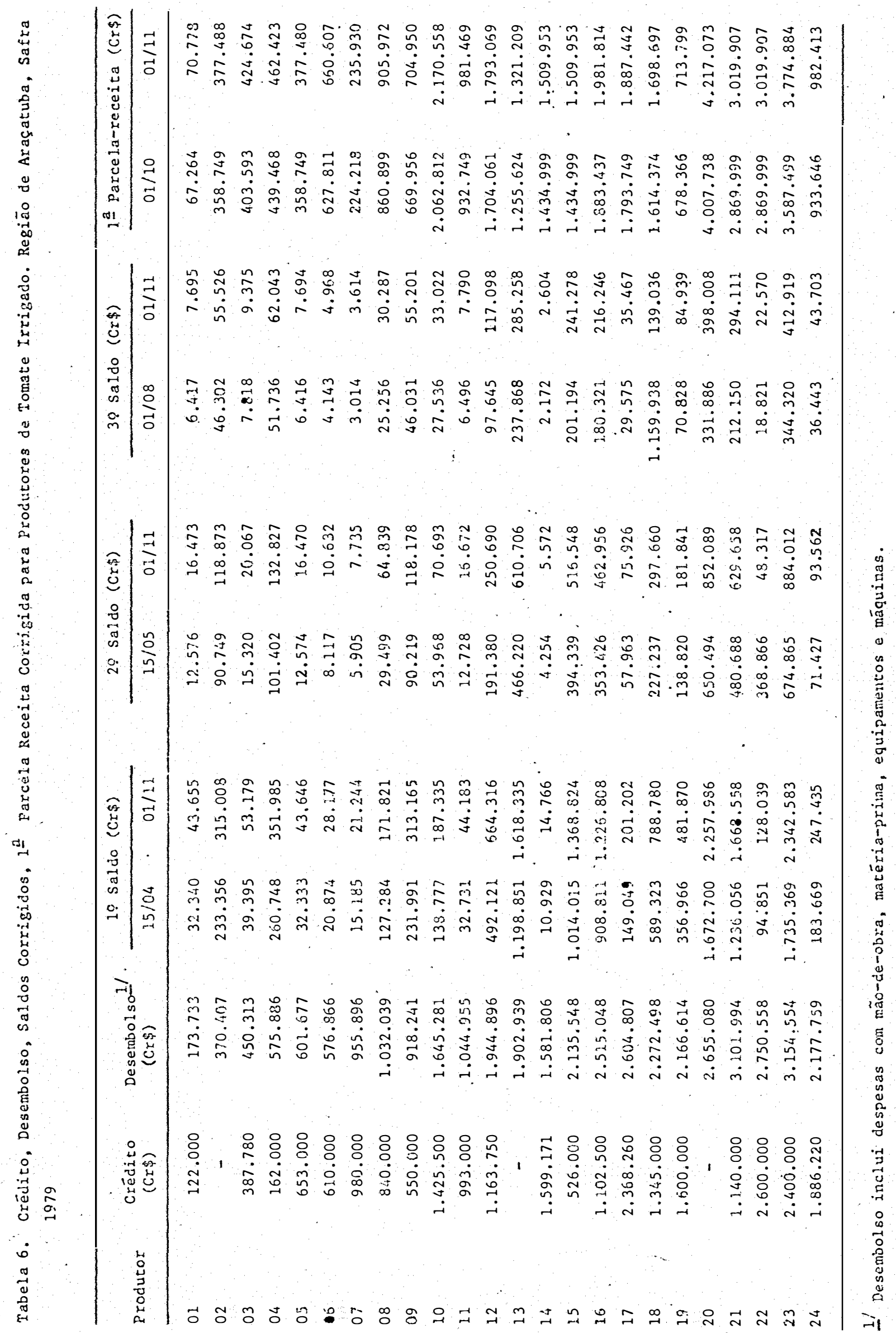




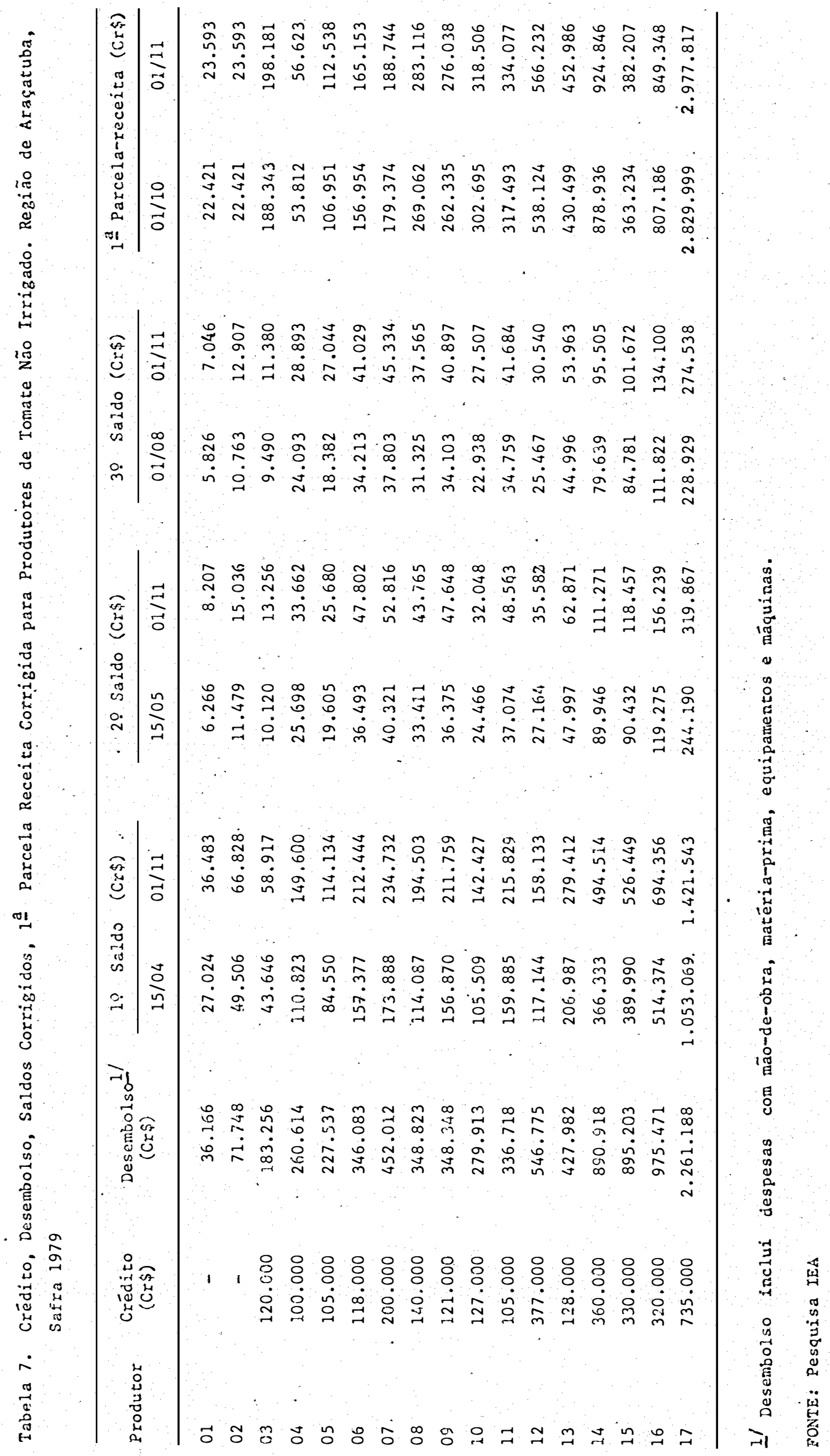


Antes, porém, cabe lembrar que devido à inexistência de informações relativas, tanto à alocação de mão-de-obra como de máquinas, a nivel da propriedade como um todo, restaram, como possibilidade, os critérios de rateio baseados na receita e na área, ambos com dados apurados pela pesquisa. Como o critério de rateio por área não leva em consideração os cultivos desenvolvidos e, sendo o tomate reconhecidamente um cultivo com gastos elevados por área, optou-se pelo critério da receita.

Assim, o critẹrio de rateio utilizado foi o percentual representado pela receita de tomate para indústria em relação à receita bruta de toda a propriedade.

As despesas a serem rateadas, segundo esse critério, são as despesas gerais (material escritório, 1icenciamento de veículos, telefone, etc), despesas com reparas em benfeitorias e instalações, despe sas com depreciação de máquinas, equipamentos, benfeitorias e instala ções, despesas com arrendamento e despesas com juros do crédito para investimento.

As siglas utilizadas nas tabelas 8 e 9 são as seguintes: 
$\mathrm{R}_{1}-1 \stackrel{\text { a }}{-}$ parcela da receita bruta, acrescida dos juros e descontado $50 \%$ do valor do minpupaI (2.5\% da receita do tnmate)

$\mathrm{R}_{2}-2 \stackrel{\text { a }}{-}$ parcela da receita bruta, acrescida dos juros e descontado os demais $50 \%$ do valor do FUNRURAL;

$A_{c}-19$ saldo corrigido, compreendendo despesas com materiais, mãode-obra, mäquinas e equipamentos;

$B_{c}-29$ saldo corrigido, compreeñdendo despesas com mão-de-obra, máquinas e equipamentos;

$c_{c}-39$ saldo corrigido, compreendendo despesas com mão-de-obra, máquinas e equipamentos;

C - Despesa referente ao principal do crédito para custeio;

G - Despesas gerais na propriedade;

R - Despesas com reparos em benfeitorias e instalações;

D - Despesas com depreciação dé mäquinas, equipamentos, benfeitorias e instalações;

$R_{L}$ - Rendimento 1íquido. 


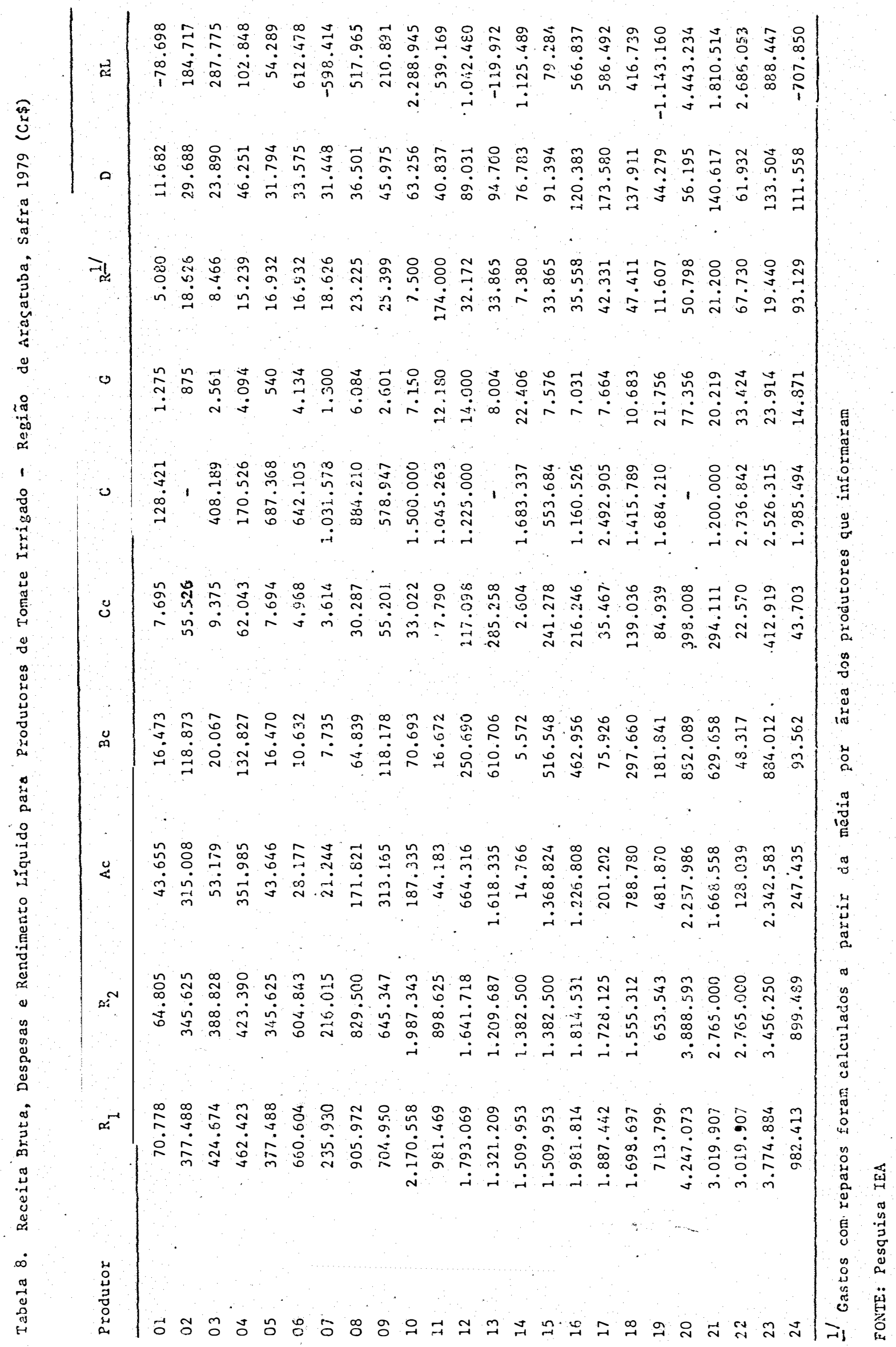




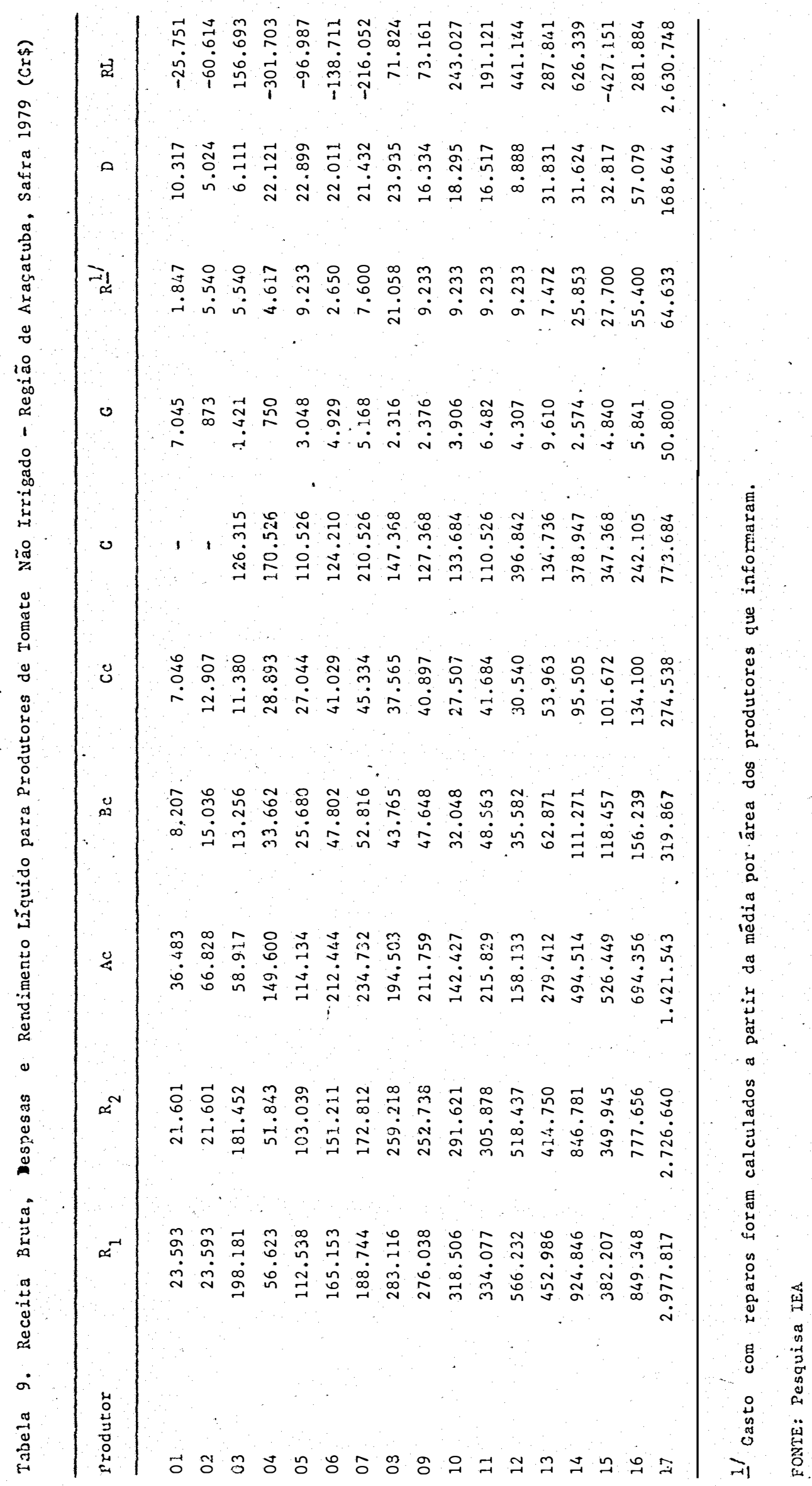


Considerados os valores pagos de arrendamento e os juros como custos para os produtores, já que correspondem a desembolsos monetärios efetivamente feitos, chega-se aos valores de "rendimento 1íquido para o produtor". As tabelas 10 e 11 apresentam estes dados.

A anālise da coluna "rendimento líquido para o produtor" da Tabela 10 mostra que dos 24 produtores de tomate irrigado, ape nas 6 (25\%) apresentaram resultado negativo. Porém, cinco desses seis produtores ficaram muito abaixo do índice médio de produtividade, atingindo, na melhor situação, 16,5 t/ha $(40 \mathrm{t} / \mathrm{alq})$. 0 último dos seis produtores com resultado negativo, embora tenha conseguido um Indice de produtividade de $28,9 \quad t / h a(70 \quad t / a 1 q)$, apresentou custos elevados (mais de $20 \%$ acima da média).

A anālise da coluna "rendimentos líquidos para o produtor" da Tabela 11 mostra, para os produtores semirrigação, que 7 dos 17 produtores apresentaram resultado negativo. Estes produtores atingiram no melhor caso, uma produtividade de 17,5 tha $(42,5 \quad t / \mathrm{alq})$.

o questionário aplicado, infelizmente, não capta o motivo da baixa produtividade desses produtores (irrigados e não irrigados), embora em dois casos haja menção à perdas decorrentes de gea da e outras adversidades climáticas (produtores números 2 e 6 de tomate não irrigado). o produtor 2 teve uma produtividade bastante baixa $(3,4 \quad t / h a$ ou $8,7 \quad t / a l q)$, explicando o motivo do resultado negativo, ao passo que o produtor 6 , embora também tenha apresentado um resultado negativo, obteve un indice de produtividade melhor ( 14,5

$$
\text { t/ha ou } 35 \text { t/alq). }
$$


Tabela 10. Rendimento Líquido, Valor Pago de Arrendamento, Juros Pagos, Rendimento Líquido para o Produtor, Produtores de Tomate Irrigado, Região de Araçatuba, Safra 1979

\begin{tabular}{|c|c|c|c|c|c|}
\hline Produtor & $\begin{array}{c}\text { Rendimento } \\
\text { líquido } \\
(\operatorname{Cr} \$)\end{array}$ & $\begin{array}{l}\text { Valor } \\
\text { arrenda- } \\
\text { mentol }\end{array}$ & $\begin{array}{c}\text { Rendimento } \\
\text { líquido me } \\
\text { nos arren= } \\
\text { damento }\end{array}$ & $\begin{array}{l}\text { Juros } \\
\text { pagos } \\
\text { Cr } \$\end{array}$ & $\begin{array}{c}\text { Rendimento } \\
\text { lïquido } \\
\text { p/produtor }\end{array}$ \\
\hline 01 & -78.698 & 11.400 & -90.098 & 6.238 & -96.336 \\
\hline 02 & 184.717 & 18.000 & 166.717 & - & 166.717 \\
\hline 03 & 287.775 & 72.960 & 214.815 & 80.971 & 133.844 \\
\hline 04 & 102.848 & 20.036 & 82.812 & 6.394 & 75.818 \\
\hline 05 & 54.289 & 54.000 & 289 & 73.965 & -73.676 \\
\hline 06 & 612.478 & 135.340 & 477.138 & 96.303 & 380.835 \\
\hline 07 & -598.414 & 37.160 & -635.574 & 38.684 & -674.258 \\
\hline 08 & 517.965 & 30.099 & 487.866 & 33.157 & 454.709 \\
\hline 09 & 210,891 & 32.460 & 178.431 & 60.117 & 118.314 \\
\hline 10 & 2.288 .945 & 402.500 & 1.886 .445 & 115.435 & 1.771 .010 \\
\hline 11 & 539.169 & 96.135 & 443.034 & 75.737 & 367.297 \\
\hline 12 & 1.042 .480 & 114.000 & 928.480 & 163.017 & 765.463 \\
\hline 13 & -119.972 & 21.750 & -141.722 & 38.628 & -180.350 \\
\hline 14. & 1.125 .489 & 163.142 & 962.347 & 63.125 & 899.222 \\
\hline 15 & 79.284 & 24.281 & 55.003 & 54.952 & 51 \\
\hline 16 & 566.837 & 69.030 & 497.807 & 126.716 & 371.091 \\
\hline 17 & 586.492 & 100.093 & 486.399 & 127.320 & 359.079 \\
\hline 18 & 416.739 & 55.740 & 360.999 & 123.849 & 237.150 \\
\hline 19 & -1.143 .160 & 259.544 & 1.402 .704 & 120.883 & -1.523 .587 \\
\hline 20 & $4.443,234$ & 730.400 & 3.712 .834 & - & 3.712 .834 \\
\hline 21 & 1.810 .544 & 650.432 & 1.160 .112 & 60.900 & 1.099 .212 \\
\hline 22 & 2.686 .053 & 249.571 & 2.436 .482 & 144.351 & 2.292 .131 \\
\hline 23 & 888.447 & 165.756 & 722.691 & 158.693 & 563.998 \\
\hline 24 & -707.850 & 448.639 & -1.156 .489 & 493.501 & -1.649 .990 \\
\hline
\end{tabular}

1

o valor de arrendamento para produtores que utilizaram terra propria para a produção de tomate foi calculado a partir da média dos valores por unidade de ärea dos produtores que arrendaram terra para tomate.

FONTE: Pesquisa IEA. 
Tabela 11. Rendimento Líquido, Valor Pago de Arrendamento, Juros : Pagos, Rendimento Líquido para o Produtor, Produtores de Tomate Não Irrigado, Região de Araçatuba, Safra 1979

\begin{tabular}{|c|c|c|c|c|c|}
\hline Produtor & $\begin{array}{l}\text { Rendimento } \\
\text { líquido } \\
\text { (Cr } \$)\end{array}$ & $\begin{array}{l}\text { Valor } \\
\text { arrenda- } \\
\text { mento } 1\end{array}$ & $\begin{array}{l}\text { Rendimento } \\
\text { liquido menos } \\
\text { arrendamento }\end{array}$ & $\begin{array}{l}\text { Juros } \\
\text { pagos } \\
\text { Cr } \$\end{array}$ & $\begin{array}{l}\text { Rendimento } \\
\text { líquido } \\
\text { p/produtor }\end{array}$ \\
\hline 01 & -25.751 & 3.702 & -29.453 & 793 & -30.246 \\
\hline 02 & -60.614 & 17,100 & -77.814 & 1.755 & -79.569 \\
\hline 03 & 156.693 & 16.312 & 140.381 & 4.736 & 135.645 \\
\hline 04 & -301.703 & 9.255 & -310.958 & 7.624 & -318.582 \\
\hline 05 & -96.987 & 18.509 & -115.496 & 5.584 & -121.080 \\
\hline 06 & -138.711 & 18.509 & -157.220 & 10.222 & -167.442 \\
\hline 07 & -216.052 & 31.920 & -247.972 & 23.964 & -271.936 \\
\hline 08 & 71.824 & 18.509 & 53.315 & 22.305 & 33.010 \\
\hline 09 & 73.161 & 42.967 & 30.194 & 23.691 & 6.503 \\
\hline 10 & 243.027 & 27.715 & 215.312 & 71.838 & 143.474 \\
\hline 11 & 191.121 & 32.550 & 158.571 & 13.351 & 145.220 \\
\hline 12 & 441.144 & 18.509 & 422.635 & 14.881 & 407.754 \\
\hline 13 & 287.841 & 22.211 & 265.630 & 13.808 & 251.822 \\
\hline $14^{\circ}$ & 626.339 & 5.389 & 620.950 & 33.362 & 587.588 \\
\hline 15 & -427.151 & 34.640 & -461.791 & 20.165 & -481.956 \\
\hline 16 & 281.884 & 106.200 & 175.684 & 9.078 & 166.606 \\
\hline 17 & 2.630 .748 & 129.437 & 2.501 .311 & 60.363 & 2.440 .948 \\
\hline
\end{tabular}

10 valor de arrend amento para produtores que utilizaram terra própria para a produção de tomate foi calculado a partir da média dos valores por unidade de àrea dos produtores que arrendaram terra para tomate. FONTE: Pesquisa IEA 
Assim, se é verdade que pequena parte dos produtores obteve "rendimento líquido para o produtor" negativo, não è menos verdade que isto foi decorrência destes produtores não atingirem índices razoáveis de produtividade para o tomate rasteiro, no ano de 1979.

Acredita-se, com base nos dados de pesquisa de 79 , que um Índice não menor que 25 t/ha seja necẹsário, em condições normais, para proporcionar lucros ao produtor de tomate irrigado, fixada uma relação preço dos insumos e preço do tọmate, além de uma tecnologia.

Por outro lado, os produtores que obtiveram índices de produtividade superiores conseguiram "rendimentos líquidos para o produtor" da ordem de, em média, $23 \%$ da receita bruta com tomate para indústria e, no caso do tonate irricado, estes produtores formam a raioria de $75 \%$.

Com base nós aspectos analisados, pode-se afirmar que os produtores de tomate rasteiro na 1 igação com a indústria de processamento obtiveram resultados nositiros. Para os que não conseguiram esse resultado, o motivo deve ser buscado, principalmente, na ocorrência de pragas e doenças, além das aciversidades climáticas. Estas peculiaridånes caracterizam o processo produtivo agnícola em geral.

Acredita-se que o resultado apurado pelos produtores de tomate irrigado da região de Araçatuba, relativamente ao percentual médio de 'rendimento líquido para o produtor', possa ser estendido para a região de Presidente Prudente, no ano de 1979. Convém lembrar que essas duas regiões juntas, por sinal as regiões novas, foram responsäveis, naquele ano, por quase $60 \%$ da produção total do Estado de . São Paulo. 
Contudo, sabe-se que os tomaticultores, em particular, se utilizam de uma prätica que pode reduzir os custos de produção. Trata-se do cultivo de um produto na mesma ārea do tomate, após sua colheita, visando aproveitar resíduos de adubação. Os produtos subseqüentes na mesma ärea costumam ser milho, feijão, cana e outros. Em certos casos, a adubação é quase que totalmente evitada na cultura seguinte, propiciando ganhos significativos ao produtor.

HOFFMANN et alii (1984, vol. IV, p. 73) apontam, para terras arrendadas e terras próprias, que ao plantio do tomate se segue o plantio de cereais e outras hortaliças, nas áreas dedicadas ao tomate, propiciando melhor utilização das máquinas e equipamentos, além de aproveitamento da adubação residual do tomate.

Ê desnecessário enfatizar que para muitas atividades agríco las é fundamental a exp̣loração simultânea ou consecutiva de atividades complementares. A rotação de culturas è apenas un exemplo dessa combinação de atividades que possibilita un melhor aproveitamento dos recursos.

Deve-se ressaltar que, na pesquisa do IEA, os adubos constituem $22,8 \%$ dos desembolsos feitos pelos produtores de tomate irrigado e $21,7 \%$ para os sem irrigação. Assim, o item adubação pode atuar no sentido de reverter a situação de alguns dos produtores com resultado negativo, em função da atribuição de uma fração dos gas tos com adubo para a cultura subsequiente, desde que existente. 
A comparação dos gastos em adubos com o "rendimento líquido para o produtor" confirma que os produtores 5 e 13 de tomate irrigado podem passar de uma situação de resultado financeiro negati vo para a de um resultado positivo. 0 produtor 5 obteria resultado positivo, se fosse alocada ao tomate até $15 \%$ dos seus gastos com adubo. 0 produtor 13 também alcançaria resultado positivo, caso fos se alocado ao tomate até $60 \%$ dos seus gastos com adubo.

Analogamente, os produtores com "rendimento líquido para o produtor" positivo podem melhorar seus resultados. Caso se considere, em um mero exercício de cálculo, que o cultivo do tomate permite um resíduo de $20 \%$ absorvido pelo cultivo subsequente, o "rendimento líquido para o produtor" médio calculado em 23\%, se elevaria para $26,4 \%$

Em termos gerais, se as pesquisas de custos levassem em conta a partição do adubo, sendo parte absorvido pelo tomate e parte pela cultura subsequente, os custos de pro dução do tomate se tornariam mais pröximos da realidade, refletindo uma prática jà conhecida dos agricultores. 
5. CARACTERISTICAS DOS PRODUTORES AGRICOLAS INTEGRADOS

Inicialmente pretende-se verificar como se comportam os produtores agrícolas analisados com respeito aos seguintes aspectos: tipo de mão-de-obra utilizada no processo produtivo do produto integrado, cultivo de lavouras e criações para subsistência, tecnologia empregada no cultivo integrado e nos demais cultivos, nível de organização dos produtores e margem de lucro obtida no produto integrado. Em seguida, se efetuará uma anālise comparativa, visando identificar fatores determinantes do marcado contraste na retenção de excedentes apresentado pelos pequenos produtores e produtores de tomate para indústria, relativamente ao produto integrado com a agroindústria.

\subsection{Pequenos Produtores}

Vamos considerar os produtores de uva de Caxias do Sul-RS, analisados por SANTOS (1978), os produtores de cana-de-açúcar de Campos -RJ, estudado por NEVES (1981) e os criadores de frango investigados por 
SORJ et alii (1982). Os produtores de leite analisado por FREDERICQ, de modo geral, não serão considerados, dada a ausência de dados na fonte bibliogräfica disponível. Qualquer referēncia a estes ültimos produtores serä feita especificamente.

A mão-de-obra utilizada por essas unidades produtivas é, de modo expressivo, familiar, sendo alocada tanto no cultivo integrado com a agroindústria, como nos outros cultivos existentes. Outra característi ca apresentada é o cultivo de lavouras de subsistência. Esse cultivo, de forma geral, apresenta um excedente em relação ao autoconsumo, que è encaminhado para o mercado. Assim, o produtor relativiza a importância da produção contratada com a agroindústria. No caso dos produtores de frango, SORJ et alii não fazem nenhuma referência específica sobre cultivos de subsistência.

Porém, uma citação sob̉re o tamanho das propriedades avíco las fornece um indício importante. "As exigências das empresas integrado ras quanto à àrea mínima da unidade produtiva a ser integrada variava de 12 a 25 ha, confome a empresa" (1982, p. 37). Mas, a tabela 2.3. do trabalho dos autores mostra que há produtores avícolas com menos de um hectare. Sabe-se da existência de, pelo menos, outro cultivo que è o mi1ho, por sinal também integrado com a agroindústria. Então, dado que o tamanho mínimo requerido para a exploração avícola é pequeno, relativamen te ao tamanho da propriedade, podendo até ser menor que um hectare, além do fato da mão-de-obra utilizada ser basicamente familiar, è provável que essa unidade produtiva cultive produtos de subsistēncia. 
Os pequenos produtores de cana-de-açúcar não detêm a propriedade dos equipamentos mecanizados mas, via aluguel, atualizam essas condições técnicas. Porém, estes equipanentos são utilizados somente nas fases de preparo do solo e semeadura, pois a utilização das ăreas intersticiais para cultivos de subsistência dificulta ou mesmo impede sua utilização (equipamentos) em fases posteriores. Os adubos e defensivos também não são utilizados por esses produtores.

Os prọdutores de uva não fazem uso de equipamentos mecani zados. Una dificuldade específica dessa região para o nível de mecaniza ção constatado: "O solo em declive dificulta a utilização de microtra"tor, quase inexistente na Região" (1981, p. 57). Contudo, fazem uso de adubo, defensivos e corretivos no cultivo contratado com a agroindústria. Os produtores de leite que fornecempara a Nestlé, no inte rior de Minas Gerais, incorporaram tecnologia moderna, represent ada pela construção de represas, silos e pela aquisição de equipamentos e máquinas.

Una característica encontrada em todos os casos analisados é a existência de associações de agricultores. A pressão exercida por estas associações é variável, dependendo de características do produto, de sua formação de preços e outras mais. Um aspecto importan te verificado para o caso da uva, e implantado posteriormente à época da pesquisa para a cana-de-açucar, é a tendência de introdução da classificação para o produto agrícola. Evidentemente, há uma necessidade técnica da indústria de processamento inspecionar e qualificar 
a matéria-prima que recebe. A indūstria requer um padrão definido e cons tante da matéria-prima para que possa ajustar o processo produtivo, visando obter certo produto final.

Mas a classificação constituiria um procedimento pu ramente técnico, em decorrência das necessidades industriais? 0 trabalho de SANTOS, sobre os produtores de uva, aponta algumas possibilidades de rebaixar o preço do produto agrícola, mediante um procedimento de classi ficação que é, na maioria das vezes, aplicado de forma a prejudicar o produtor agrícola, Ressalte-se que a definição do preço nominal permanece importantę, como acerto entre a classe dos produtores agrícolas e das indüstrias de processamento, com a mediaçãc do Estado. Porém, o procedimento de classificação, conquanto apresente uma base técnica, parece des1o car a questão do preço: pago ao produtor da órbita da discussão entre associações para uma discussão, posterior, entre uma particular indústria e um particular produtor, a qual acontece na porta da fábrica, sobre um produto, na maioria das vezes, perecível. Nessa linha de raciocinio, o pro cedimento de classificação contém uma dimensão política, distinta de sua dimensão técnica, que visa reduzir a eficácia do mecanismo de pressão re presentado pelas associações de produtores.

\subsection{Produtores de Tomate}

Os produtores de tomate para indústria analisados nesta pesquisa apresentam traços diferentes, conforme produzam tomate com irri gação ou sem irrigação. 
A área plantada com tomate, na safra de 79 , era de 62,5 ha, em média, para os produtores de tomate irrigado e de 21,3 ha, em media, para os produtores de tomate não irrigado*.

Verificar-se que $40 \%$ dos produtores de tomate irrigado cultivaram áreas maiores que 50 ha com tomate. $52 \%$ desses produtores cul tivaram āreas entre 20 e 50 ha e somente dois produtores da amostra cultivaram äreas menores que 20 ha com tomate. Jä os produtores de tomate não irrigado cultivaram āreas bem menores, jā que a média de sua área es tá pouco acima de $20 \mathrm{ha}$. Somente dois produtores cultivaram mais que 50 ha com tomate. Onze produtores cultivaram áreas entre 12 e 50 ha, sendo que oito deles cultivaram 12 ha. Os quatro produtores restantes, dos 17 totais sem irrigação, cultivaram äreas por volta de 6 ha.

A mão-de-obra utilizada no cultivo de tomate é predominan temente não familiar, conforme mostram as tabelas 12 e 13 .

Os produtores de tomate não irrigado utilizam, em média, $17 \%$ da mão-de-obra total utilizada para tomate de mão-de-obra familiar. Somando-se a mão-de-obra permanente à familiar, esse percentual atinge $20 \%$. Jả os produtores de tomate irrigado utilizam apenas $1,5 \%$, em média, de mão-de-obra familiar. A soma da mão-de-obra permanente com a familiarre presenta 3,9\% da mão-de-obra total utilizada. Nota-se que os produtores de tomate não irrigado mostram um participação razoável da mão-de-obra fa miliar no processo produtivo, ao passo que essa mesma participação para o tomate irrigado é bem pequena,

* Tabelas 4 e 5 deste trabalho, páginas 52 e 53 , respectivamente. 
Tabela 12. Mão-de-obra utilizada por produtor no cultivo de tomate irrigado, Araçatuba safra de 1979 e número de tratores nor produtor.

\begin{tabular}{|c|c|c|c|c|c|}
\hline & \multicolumn{2}{|c|}{ MÃO-DE-OBRA } & \multicolumn{2}{|l|}{ (dias. homem) } & \multirow[b]{2}{*}{$\begin{array}{l}\text { NO DE TRA- } \\
\text { TORES }\end{array}$} \\
\hline PRODUTOR & FAMILIAR & RESIDENTE & TEMPORĀRIA & COLHEITA & \\
\hline 1 & 22 & - & 240 & 7,5 & 1 \\
\hline 2 & 2 & - & 268 & 444,5 & 2 \\
\hline 3 & 104 & - & 392 & 500 & 2 \\
\hline 4 & 220 & - & 758 & 544,5 & 2 \\
\hline 5 & - . & - & 599 & 444,5 & 1 \\
\hline 6 & 27 & - & 279 & 777,7 & 3 \\
\hline 7 & - & - & 1131 & 277,7 & 2 \\
\hline 8 & 229 & - & 686 & 1066,6 & 2 \\
\hline 9 & 30 & $=$ & 565 & 833,3 & 3 \\
\hline 10 & - & - & 1204 & 2555,5 & 6 \\
\hline 11 & - & 29 & $\therefore-$ & 1444,4 & 3 \\
\hline 12 & 62 & $=$ & 1061 & 2111,2 & 4 \\
\hline 13 & - & $=$ & 1000 & 1555,5 & 3 \\
\hline 14 & - & - & 2030 & 1777,7 & 3 \\
\hline 15 & 103 & - & 1721 & 1777,7 & 5 \\
\hline 16 & 131 & - & 413 & 2333,3 & 4 \\
\hline 17 & - & - & 1296 & 2222,2 & 5 \\
\hline 18 & 5 & - & 1680 & 2000 & 4 \\
\hline 19 & 290 & 283 & 6180 & 840,5 & 4 \\
\hline 20 & - & 711 & 630 & 5000 & 6 \\
\hline 21 & - & - & 6913 & 3555,5 & 6 \\
\hline 22 & - & 172 & 701 & 3555,5 & 7 \\
\hline 23 & - & - & 3897 & 4444,4 & 6 \\
\hline 24 & 25 & 686 & 1803 & 1156,6 & 8 \\
\hline 25 & & & & & 10 \\
\hline TOTAL & 1249 & 1831 & 35452 & 41226 & 102 \\
\hline MEDIA & 52 & 78 & 1477 & 1717 & 4,08 \\
\hline
\end{tabular}

Fonte: Pesquisa IEA 
Tabela 13. Mão-de-obra utilizada por produtor no cultivo de tomate não irrigado, Araçatuba safra de 1979 e número de tratores por produtor.

\begin{tabular}{|c|c|c|c|c|c|}
\hline \multicolumn{3}{|c|}{ MÃO-DE-OBRA } & \multicolumn{3}{|c|}{ (dias.homem) } \\
\hline PRODUTOR & FAMILIAR & RESIDENTE & TEMPORARIO & COLHEITA & NO TRATORES \\
\hline 1 & 66,5 & - & - & 27,7 & 2 \\
\hline 2 & - & 26 & 30 & 27,7 & 3 \\
\hline 3 & - & - & 38 & 233,3 & 2 \\
\hline 4 & 259 & - & 50 & 66,6 & 2 \\
\hline 5 & 25,5 & 47,5 & 86 & 132,5 & $\mathrm{i}$ \\
\hline 6 & 239 & - & 187 & 194,4 & 1 \\
\hline 7 & - & 157 & 140,5 & 222,2 & 2 \\
\hline 8 & - & 57,5 & 290 & 333,3 & 2 \\
\hline 9 & 64,5 & - & 411 & 324,4 & 1 \\
\hline 10 & 256 & 48 & 110 & 375 & 1 \\
\hline 11 & 84 & - & 89 & 388,9 & 2 \\
\hline 12 & 26 & 218 & 168 & 666,6 & 2 \\
\hline 13 & 190 & - & - & 898 & 2 \\
\hline 14 & 52 & - & 696 & 1088,9 & 2 \\
\hline 15 & 1336 & - & - & 450 & 2 \\
\hline 16 & 183 & - & - & 1000 & 3 \\
\hline 17 & 139 & - & 1671 & 3500 & 3 \\
\hline TOTAL & 2947 & 528 & 3966 & 9930 & 33 \\
\hline MEDI A & 173,3 & 31 & 233,3 & 583,5 & 1,94 \\
\hline
\end{tabular}

Fonte: Pesquisa IEA 
Quatro dos 17 produtores de tomate não irrigado não utilizam mão-de-obra familiar no processo produtivo, enquanto outros quatro, exceção feita à fase da colheita, não utilizam mão-de-obra assalariada. Por sua vez, a mão-de-obra permanente estä concentrada em somente seis produtores.

Onze dos 2.4 produtores de tomate irrigado não utilizam mão-de-obra faniliar, ao passo que todos utilizam mão-de-obra assalariada. Analogamente, a mão-de-obra permanente encontra-se concentrada em cinco produtores.

A anālise das taref as constantes do ciclo produtivo mostra que para os produtores de tomate não irrigado a mão-de-obra familiar é alocada em diversas tarefas. Jä no caso dos produtores de tomate irri gado a mão-de-obra familiar é utilizada apenas nas operações cue exiger: maior cuidado. Contudo,em vários produtores se nota a substituição da mão-de-obra familiar pela mão-de-obra permanente, deno tando, talvez, uma concentração da mão-de-obra familiar nas taref as comer ciais ligadas ao ciclo produtivo do tomate, como financiamentos, seguros, compra de adubos, contatos para comercialização da colheita, etc.

Embora os questionários mostrem que os produtores de tomate também cultivan milho, feijjão, arroz, alêm da soja e aleocaãa, nãa hä informações que permitam avaliar a îmoortância da produçâa para auto consumo. Tendo em vista o nỉvel econômico atingido por esses produtores, acredita-se que aquela produção seja fundamentalmente destinada à comercialização.

A base técnica de produção mostra como diferença inicial - fato de a maioria dos produtores anostrados (60\%) possuir aparelho (s) de irrigação. Esses produtores, como já citado, cultivam áreas maiores 
com tomate, em decorréncia do nível econōmico que atingiram. Possuiam uma média de pouco mais de quatro tratores. Observa-se, em geral, un volume maior de equipamentos nestes produtores comparativamente àqueles sem irrigação.

Os produtores de tomate não irrigado possuem una média infe rior a 2 tratores por estabelecimento, o que contribui para explicar a ārea média cultivada com tomate ser menor. Nota-se tambēm una concentração de equipamentos manuais nestes produtores. (Ver Tabelas 12 e 13).

Esta diferença de base técnica permite que se entenda a diferença de produtividade entre esses grupos de produtores de tomate. Constatou-se, para o ano de 79, que os produtores de tomate irrigado obtiveram uma produtividade de $31,8 \mathrm{t} / \mathrm{ha}$, enquanto que os produtores de to mate não irrigado conseguiram uma produtividade de 24,9 t/ha. Segundo in formações dos técnicos do IEA encarregados da pesquisa, essa. diferença, $27 \%$, teria sido menor do que costuma ser, uma vez que o regime de chuvas propiciou una boa colheita naquele ano, beneficiando particularmente aos produtores de tomate não irrigado.

Os produtores de tomate para indústria utilizam adubos e defensivos em quantidade considerävel. Vale lembrar que cerca de $22 \%$ dos desembolsos feitos por estes produtores, com ou sem irrigação “ , são feitos com adubos. Os gastos com defensivos representam um percentual maior ainda, sendo de $33 \%$ dos gastos totais para os produtores de tomate irrigado e de $27,4 \%$ para os produtores de tomate não irrigado.

o Comitê da Agroindústria é o fôro onde se discutem os in teresses da indústria de processamento e de seus fornecedores. Esta reuni ão congrega represent antes da associação dosprodutores (FAESP), da as- 
sociação das indústrias (ABIA), dos consumidores (Secretaria da Agricultura). Nota-se, também, a presença de produtores de tomate, de representantes das associações de cooperativas, de representantes das indústrias.

Os preços para a safra de determinado ano do tomate rasteiro são definidos nessa reuniãă. A frequência dessas reuniões varia, dependendo dos problemas a serem analisados. A consulta às at as de 1979 mostra que houve alguns meses sem reuniões mas, por outro lado, em junho aconteceram 3 reuniões para se tentar acertar o preço da safra. Observou-se que as indūstrias vêm o preço definido no Comitê como um preço mínimo. Caso as necessîdades de una particular indústria sejam maiores em certo momento, ocorre o pagamento de "prêmios". Dess a forma, as indústrias podem competir pelo produto dos fornecedores. Assim é que constatou-se que os produtores não concordaram com a proposta das indús trias e relutavan, tendo a CICA em momento anterior à pesquisa pago $\operatorname{Cr} \$ 1,92 / \mathrm{kg}$.

No ano da pesquisa, $75 \%$ dos produtores de tomate irrigado obtiveram um rendimento líquido médio de $23 \%$ da receita bruta obtida com tomate para indústria. Dez dos produtores de tomate não irrigado obtiver am um rendimento líquido médio de $31 \%$ da receita bruta obtida com tomate para indústria. Efetivamente, constata-se que o cultivo de tomate proporciona altas margens líquidas, embora implique alto risco para o produtor agrícola. 


\subsection{Anälise comparativa}

0 produtor de tomate para indústria apresenta diferenças significativas, se comparado com os pequenos produtores de frango, cana-de-açúcar, uva ou leite analisados anteriormente.

Tudo indica que os produtores familiares obtém taxa de $1 u-$ cro inferior aos produtores capitalistas de tomate para ind ústria.

Desse modo, a retenção de excedente gerado na produção agrí cola apresenta um marcado contraste, conforme se observe um ou outro grupo de produtores agrícolas.

Então, produtores que vendem seus produtos basicamente para a agroindüstria podem reter, em graus diferentes, o excedente gerado na produção. A que fatores atribuir essas diferenças? A confrontação das características dos dois grupos de produtores, provavelmente, fornecerá indícios para responder a esta questão. Deve ser lembrado que estas características decorrem também da interação do produtor agrícola com a agroindústria.

Assim, para os produtores de tomate irrigado com äreas de tomate inferiores a 50 ha notou-se maior presença da mão-de-obra familiar nas tarefas mais importantes do cultivo do tomate, isto é, o preparo do solo; a semeadura, as pulverizações, alëm de algumas atividades na colheita, quais sejam esparramar caixas, transporte da produção,trans porte de pessoal que $f a z$ a colheita. A alocação da mão-de-obra familiar às atividades iniciais parece ser explicada pela necessidade de cuidados especiais na condução desse cultivo. Essas fases são nevrálgicas para a 
cultura do tomate, daí a atuação direta da famĩlia Já as tarefas de coTheita parecem prender-se tanto a uma necessidade de garantir a mão-de-o bra temporária, através do transporte, como à fiscalização da colheita, re presentada pelas tarefas de esparramar caixas, transporte da produção e outras.

Na região de Araçatuba, no ano da pesquisa, não foi observada uma alocação pura e simples da mão-de-obra familiar nas tarefas mais especializadas, como a operação do trator*. Cabe destacar o elevado número de tratores, em média, por propriedade: quatro. A importância da operação do trator pela mão-de-obra familiar certamente deve ser secundāria. Notou-se, isso sim, uma atuação mais intensa, no estrato inferior a 50 ha, de não-de-obra familiar nas tarefas nevrälgicas, como pul verização do tomateiro e outras. 0 alto risco do cultivo requer cuidados especiais que implicam a atuação direta da famỉila.

Os produtores de tomate irrigado con áreas șueriores, a $50 \mathrm{ha}, 10$ dentre os 25 totais; mostram uma presença maior de mão-de-obra residente, a qual assume e supervisiona as tarefas principais. Por outro lado, em cinco dessas unidades a mão-de-obra famíliar não é uti lizada em taref as do ciclo produtivo e em outras duas a atuação é bastante pequena.

Então, as tarefas rotineiras são delegadas à mão-de-obra assalariada, ainda que sob a fiscalização de empregados residentes. A família, nesse caso, se ocupa das tarefas não diretamente pertencentes ao ciclo produtivo do tomate, tais como os contatos externos para financiamento, seguro, ace rtos bancários, comercialização da colheita, compra de in

* Ver SAles a este respeito (p. 22). 
sumos, que cada vez mais absorvem sua atenção e cuidado. Isto não a exime, no entanto, de visitas eventuais à área de tomate para checar o cum primento de suas instruções. Nesse caso, a propriedade agricola dedicada à exploração do tomate para indústria parece aproximar-se de uma empresa capitalista.

Em suma, se uma parcela não desprezível de produtores de tomate cultiva āreas maiores e, simultaneamente, consegue se desligardas tarefas produtivas, è sinal que toma corpo, entre os agricultores, a idéia de que o cultivo do tomate pode ser conduzido em padrões capitalistas. Por outro lado; na diminuição do risco, atualmente alto, desse cul tivo è que pode estar a chave para a concentração da produção de tomate para indústria em àreas maiores.

Já os pequenos produtores analisados empregam a mão-de-obra familiar de forma intensiva no processo produtivo tanto para o cultivo in tegrado com a indústria como para os outros cultivos comercializados no mercado, lembrando-se que esses cultivos atendem, subsidiariamente, o autoconsumo da familia.

A integração da pequena produção com a agroindústria, segur do SORJ e WILKINSON, implica que "a possibilidade de escolher entre o au toconsumo e a mercantilização não mais existe" (1983, p. 172). Com efe to, os casos analisados mostram uma redefinição da unidade produtiva, on de a função de garantir a subsistência é reduzida e secundarizada pelo encaminhamento para mercado dos produtos cultivados e não contrat ados com a agroindústria. Anteriormente a essa vinculação, esses cultivos cumpriam, primordialmente, a função de cultivos para subsistēncia da pequena produção. Quer-se enfatizar, com esse comentārio, que a integração com a ind ústriade processamento não leva à eliminação de todos os outros 
cultivos, mas que, embora o cultivo contratado adquira uma importância maior, o cultivo de outros produtos (primeiramente para mercado e secun dariamente fara autoçonsumo) é extremamente importante, no sentido de relativizar a integração do pequeno produtor com a agroindústria. Assim, a esfera da circulação das mercadorias cumpre papel importante na reordenação da unidade familiar integrada com a agroindústria.

Os produtores de tomate cultivam outros produtos, seja na ārea arrendada paxa tomate, seja na ärea de sua propriedade. Esses cul tivos destinam-se, principalmente, a reduzir o nível de risco na propriedade como um todo, dado o grau elevado de risco proveniente do cul tivo de tomate. 0 nível econômico atingido por esses produtores des1oca, com toda certeza, a possibilidade de cultivar para subsistência. As sim, embora os produtores de tomate sejam especialistas na condução dessa cultura, não se restringem somente a esse cultivo.

0 nivel tecnológico dos produtores de tomate mostra-se elevado, tanto no que se refere à mecanização, como na utilização de adubos, defensivos, sementes, etc. Esse patamar tecnológico estende-se aos outros cultivos existentes em sua propriedade e nas āreas arrendadas para tomate. Já os pequenos produtores apresentam um nível tecno 1ógico não uniforme, se analisada a propriedạde da forma total. No pro duto contrat ado com a agroindústria a mecanização se encontra presente, ora caracterizada pela simples posse, via alugue 1, dos equipamentos me canizados, ora caracterizada pela propriedade efetiva desses equipamen- 
tos. A utilização de adubos e defensivos nem sempre ocorre, embora seja mais freqülente.

Note-se, entretanto, que esses produtores restringem a utilização da tecnologia, em geral, somente ao cultivo contratado, sendo as outras culturas desenvolvidas em bases mais tradicionais, isto è, com terra e trabalho (familiar).

Os traços gerais evidenciados permitem afirmar que o produtor de tomate para indústria opera em bases capitalistas. Utiliza intensivamente mão-de-obra assalariada, dedicando-se a família somente à organização do processo produtivo.

O nivel econōmico atingido por estes agricultores é caracte rizado pelo grande volume de capital fixo na forma de equipanentos. Observa-se elevado nümero de tratores (hä produtores com 8 tratores) e aparelhos de irrigação. E comum a ocorréncia de produtores com 2 conjuntos de irrigação, bem como pulverizadoras, colhedeiras, de outros produtos e outros equịpamentos. Não possuem, entretanto, grandes extensões de terra, pois o tomate è cultura itinerante. Mas, mesmo com respeito à ärea de arrendamento podem ser caracterizados como médios ou grandes produtores. Existem produtores com àreas de cultivo de tomate para indústria em torno de 100 ha, havendo inclusive un com 338 ha.

Por sua vez, o produto tomate apresenta aspectos que se destacam frente a um produto agrícola qualquer. O risco dessa cultura è alto, em decorrēncia do elevado nümero de doenças que podem acometê-1a. As perdas podem atingir nümero relativamente alto de produtores, comprome 
tendo, então, o processo produtivo da indüstria. o risco alto dificulta ou até impede a entrada de novos produtores nesse setor.

Assim, o poder de barganha desses produtores, organizados em associações, deve ser considerável. A competição pela apropriação do excedente, em situações como essa, torna-se bem menos desfavorável para o produtor agrícola.

Entretanto, a retenção de excedentes pelo setor agrícola pode ser incrementada, nas situações constatadas para o tomate. Verificou-se para 1979, pela consulta às at as de reuniões do Comitê de Agroin dústria, a existência de una certa concorréncia entre as indústrias de processamento. Como jà descrito, a CICA pagava um prêmio de $10 \%$ aos produtores que the vendiam a produção. Contudo, tem-se conhecimento de outros procedimentos que proporcionam ganhos adicionais ao produtor de toma te. Entrevista recente com um administrador de certa indústria processadora revelou que ocorrem, não raro, convites para desvio de produção, me. diante o pagamento de taxas extras, quando do transporte do produto; em plena rodovia.

Por outro lado, os pequenos produtores baseados no trabalho familiar apresentam caracteristicas distintas. As baixas margens de lucro parecem ser explicadas pela pulverização excessiva da produção entre um grande contingente de produtores, além é claro, do baixo nível de organização para defesa de seus interesses. As associações existem, mas parecem seguir parānetros que não refletem totalmente os interesses de classe dos produtores filiados. 
Nessa perspectiva, a apropriação de excedentes pelos produtores agrícolas integrados com a agroindústria dependeria da capacidade de barganha de cada setor agrícola frente ao setor agroindustrial. Esta capacidade estaria baseada en duas características: o tamanho dos produto res agrícolas do setor particular e a eficācia na organização de seus interesses. 
6. CONCLUSÕES

A anälise de uma amostra de produtores de tomate para indústria, mostrou que o agricultor obteve resultado económico positivo o que, aliàs, explica sua continuidade na exploração de tonate para indús tria. o intervalo de tempo médio que os produtores cultivavam tomate, segundo a pesquisa, era de cerca de 5 anos.

Setenta e cinco porcento dos produtores de tomate irrigado apresentaram um resultado positivo médio de $23 \%$, na safra de 1979 , e dos seis produtores restantes que não acusavam resultado positivó, cinco não atingiram niveis de produtividade razoáveis.

Assim, tanto a revisão dos trabalhos de que se tem conhecimento, como a pesquisa base deste trabalho apontam para a conclusão que - produtor de matéria prima para a indüstria de transformação se apropria de parte do excedente gerado na produção.

Constatou-se também que o produtor de tomate irrigado se aproxıma bastante do empresảrio agrícola capitalista, enquanto que os 
outros produtores agrícolas se enquadram tha sategoria dos pequenos produtores familiares. A capacidade de barganha desses dois grupos parece ser bast ante di ferenciada.

o produtor agrícola não permanecerá ligado à indústria de processamento, caso tenha prejuízos continuamente. Como explicar (como quer em SORJ e WILYINSON) a seleção, pela agroindüstria, de produtores atualizados tecnologicamente, os quais não conseguem vantagens econōmicas ? 0 que estaria movendo este produtor agrícola? A pesquisa de FREDERICQ, relativa aos produtores de leite, mostra que a mudança de exploração ocor rerá, na maioria das vezes.

Contudo, há alternativas mais simples utilizadas pelo produtor agrícola. A margem de manobras do produtor, pode ser, dependendo do produto, bastante ampla, de modo a permitir a simples mudança de compra dor para o seu produto. As vezes, o produtor nem cumpre o contrato previamente acertado com a indústria de processamento, sendo esse um dos motivos básicos pelo qual as indústrias procuram contratar produtores pró ximos. Não raro, outras indústrias tentam contatar o produtor em sua propriedade agrícola ou, como nos dias atuais, segundo informaçōes colhidas junto à uma agroindústria de tomate, nas rodovias. A estratégia è simples e consiste em pagar um preço superior.

Deve-se ressaltar que há alternativas para o produtor agrí cola. A maioria das tecnologias não è tão específica a ponto de inviabilizar qualquer alteração nas atividades desenvolvidas.

Mesmo nos casos eventuais em que a tecnologia é mais especí 
fica, como parece ser na atividade avícola, constatou-se que o conjunto das atividades integradas com a agroindústria é lucrativo, pois se assim não fosse, o produtor mudaria de atividade.

Uma outra conclusão, também reforçada pela revisão aqui feita, embora não privilegiada na pesquisa-base deste trabalho, é que as relações entre cultivos complementares não são analisadas com o devido grau de importância que apresentam na realidade; o agricultor, não é de hoje, efetua rotações de cultivos também por motivos econômicos, visando alocar o mais eficientemente possivel os recursos de que dispõe, ou seja, mão-de-obra, materiais, terra, equipamentos.

Algumas vezes, a incorreta avaliação da realidade acaba respaldando, como foi visto aqui, a afirmação de que os produtores se ligam à indūstria sem obter lucro. E necessário certo cuidado na alocação das quantidades de cada fator que foram consumidas no processo produtivo de determinado produto.

Decorre desta última conclusão, uma sugestão visando a contribuir para o aperfeiçoamento da coleta de dados e das estruturas de custos agrícolas.

As instituições encarregadas de elaborar estimativas de custo enxergam a propriedade agrícola como produtora de certo produto. Este produto è isolado, para as estimativas de custo, sendo des lo cada a análise das relaçōes internas entre os cultivos. Considera-se, contrariamente à prática do agricultor, que os gastos feitos pelo agri cultor com o adubo, por exemplo, foram absorvidos totalmente pelo cultivo em análise. Embora não haja, na maior partè dos casos, critérios 
que respaldem uma certa participação percentual do adubo para cada cul tivo, duàs alternativas se colocam para a apuração de um custo mais representativo da realidade: ou se estabelecencritérios econômicos de partição, ou se considera o conjunto de cultivos para a estimativa dos custos. Ambas as alternativas, de modo geral, apontam para a defi nição de conjuntos-padrão de cultivos cọmo soja-trigo, cana-amendoim, cana-tomate. Caracteristicas do solo, clima e outras influiriam na determinação desses conjuntos.

Nos dois casos, porēm, o reflexo na ärea da pesquisa agronômica se faz sentir pela necessidade premente de caminhar-se no entendimento dos critérios gerais que presidem a combinação de cultivos. Já se encontra desenvolvido o aspecto de compatibilidade entre cultivos, mas o que se coloca aqui são as combinações.. econômicas de cultivos, levando-se em conta, principalmente, a adubação. 


\section{BIBLIOGRAFIA}

ALBUQUERQUE, R.H.P.L., 1982. Capital Comercial, Indüstria Textil e Produção Agrícola. Editora Hucitec. São Paulo, 268p.

BEMELMANS, P. et alii, 1980. Coeficientes Técnicos para Estimativas de Custo de Produção de Tomate Rasteiro. p.35-47. In: Informações Econômicas 3/80. Secretaria da Agricultura, IEA, São Paulo.

CANO, W., 1977. Raĩzes da Concentração Industrial em São Paulo. DIFEL, São Paulo, 317p.

GRAZIANO DA SILVA, J.F., 1980. Progresso Técnico e Relações de Trabalho na Agricultura Paulista. UNICAMP. Campinas. Tese de Doutoramento. Vo1. 1, 133p.

GUIMARÃES, A.P., 1976. O Complexo Agroindustrial no Brasil. p.8-11. In: Jornal Opiniã. 5/11, 15p. 
GUIMARÃES, A.P., 1979. Crise Agräria. Editora Paz e Terra. Rio de Janeiro, $362 \mathrm{p}$.

HOFFMANN, R. et alii, 1985. Inovaçöes Tecnolögicas e Transformações Recentes na Agricultura Brasileira. FEALQ, Piracicaba, 4 vols.

KAGEYAMA, A., 1984. Agroindústria. Conceitos e Parāmetros Principais

In: GRAZIANO DA SILVA e W. CANO. Condições de Operações da Agroindūs tria Paulista. Vo1. II, UNICAMP, Campinas, 19p.

MARX, K., 1985. O Capital. Vol. I, Tomo I. Nova Cultural. São Paulo. $301 \mathrm{p}$.

MARX, K., 1985a. O Capital. Vol. II. Nova Cultural. São Paulo. 383p.

MATSUNAGA, M. et alii., 1976. Metodologia de Custo de Produção Utiliza-da pelo IEA. p.123-139. In: SÃO PAULO. Secretaria da Agricultura. Instituto de Economia Agricola. Agricultura em São Paulo. São Paulo. Ano XXIII, Tomo I.

MEIRELIES, P.C.P., 1962. Aspectos Econōmicos da Cultura de Tomate na Região de Indaiatuba. p. 47-58. In: SÃO PAULO. Secretaria da Agri cultura. Instituto de Economia Agrícola. Agricultura em São Pauls. São Paulo, Ano IX, nọ 2. 
MULleR, G., 1980. Estrutura e Dinâmica do Complexo Agroindustrial Brasileiro. USP, São Paulo. Tese de Doutoramento. $271 \mathrm{p}$.

MULler, G., 1982. Estado e Classes Sociais na Agricultura. p.81-94. In: Estudos Econômicos. IPE-USP. Vol, 12. n? 2.

NAPOLEONI, C., 1981. Lições sobre o Capital VI (inēditol de Marx. Editora Ciências Humanas. $173 \mathrm{p}$.

NEVES, E.M. e M. MATSUnAGA, 1969. Cus to de Produção de Tomate de Chão na Região de Taquaritinga: Tração e Motomecanizada. p.47-64. In: SÃo PAULO. Secretaria da Agricultura. Instituto de Economia Agrícola. Agricultura em Sä Paulo. São Paulo. Ano XVI, nọs 5/6.

NEVES, D.P., 1981. Lauradores e Pequenos Produtores de Cana. Zahar Editores. Rio de Janeiro, 212p.

REISS, G.D., 1983. Formação da Empresa Industrial. p.67-101. In: Revista de Economia Politica, Vo1. 3, no 2, Editora Brasiliense. São Paulo. 160p.

SAIES, T., 1985. Tomaticultores no Estado de São Paulo: Questões sobre a Produção Familiar na Agricultura. Cadernos CEBRAP nọ 5, Nova Sërie.

SANTOS, J.V.T., 1978. Colonos do Vinho. Editora Hucitec. São Paulo. 182p. 
SÃO PAULO. Secretaria de Agricultura e Abastecimento. Instituto de Economia Agrícola, 1984. Informações Econômicas 7/84.

SINGER, P.I., 1968. Desenvolvimento Econômico e Evolução Urbana. Compa nhia Editora Nacional. São Paulo, $377 \mathrm{p}$.

SorJ, B., 1980. Estado e Classes Sociais na Agricultura Brasileira Zahar Editores. Rio de Janeiro, 152p.

SORJ, B., M.J. POMPERMAYER e O.L. CORADINI, 1982. Camponeses e Agroin düstria. Zahar Editores, Rio de Janeiro, 119p.

SORJ, B. e J. WILKINSON, 1983. Processos Sociais e Formas de Produção na Agricultura Brasileira. p. 164-190. In: SORJ, B. e M.H.T. AI MEIDA, Org. Sociedade e Polética no Brasil pós. 64. Editora Brasi liense. São Paulo, 261p.

SZMRECSANYI, T., 1983. Análises de Economia Agricola e da Questão Fun diära. UNICAMP. Campinas, 90p. (Cadernos IFCH-UNICAMP 7).

VIotti DA costA, E., 1966. Da Senzala à Colônia. DIFEL, são Paulo . 497p. 